University of Nebraska - Lincoln

DigitalCommons@University of Nebraska - Lincoln

College of Law, Faculty Publications

Law, College of

2007

\title{
Mississippi River Stories: Lessons from a Century of Unnatural Disasters
}

Sandi Zellmer

University of Nebraska Lincoln, szellmer2@unl.edu

Christine Klein

University of Florida, kleinc@law.ufl.edu

Follow this and additional works at: https://digitalcommons.unl.edu/lawfacpub

Part of the Constitutional Law Commons, Environmental Law Commons, Law and Society Commons, Legal Studies Commons, Natural Resources Law Commons, and the Water Law Commons

Zellmer, Sandi and Klein, Christine, "Mississippi River Stories: Lessons from a Century of Unnatural Disasters" (2007). College of Law, Faculty Publications. 12.

https://digitalcommons.unl.edu/lawfacpub/12

This Article is brought to you for free and open access by the Law, College of at DigitalCommons@University of Nebraska - Lincoln. It has been accepted for inclusion in College of Law, Faculty Publications by an authorized administrator of DigitalCommons@University of Nebraska - Lincoln. 


\title{
MississipPi River STORIES: LESSONS FROM A CENTURY OF UnNATURAL DisASTERS
}

\author{
Christine A. Klein* \\ Sandra B. Zellmer**
}

In the wake of Hurricane Katrina, the nation pondered how a relatively weak Category 3 storm could have destroyed an entire region. Few appreciated the extent to which a flawed federal water development policy transformed this apparently natural disaster into a "manmade" disaster; fewer still appreciated how the disaster was the predictable, and indeed predicted, sequel to almost a century of similar disasters. This Article focuses upon three such stories: the Great Flood of 1927, the Midwest Flood of 1993, and Hurricanes Katrina and Rita of 2005. Taken together, the stories reveal important lessons, including the inadequacy of engineered flood control structures such as levees and dams, the perverse incentives created by the national flood insurance program, and the need to reform federal leadership over flood hazard control, particularly as delegated to the Army Corps of Engineers.

Setting forth what we call the theory of "double takes," this Article argues that property owners in flood-prone areas "take" taxpayer dollars through two sometimes overlapping mechanisms. First, a package of subsidies-including flood control structures, federal flood insurance, and after-the-fact disaster relief-enables and even encourages construction in high-risk areas. As a consequence, many floodplain residents are lured into harm's way. Second, landowners denied permits to develop floodplain and coastal property can "take" federal or state dollars in the form of compensation awarded under the Fifth Amendment. At times, the same landowner-or even the same parcel of land - may benefit simultaneously from both mechanisms, as in the case of large-scale developers enjoying subsidized levee protection for portions of the land and receiving Fifth Amendment compensation for other portions where development is precluded. Such claims for compensation are fostered by the 1992 decision in Lucas v. South Carolina

* Associate Dean for Faculty Development and Professor of Law, University of Florida, Levin College of Law. LL.M., Columbia University; J.D., University of Colorado; B.A., Middlebury College. I am grateful to Heather Halter, Ling-Yee Huang, and Samantha Alves Orender for their research assistance, and to the University of Florida for providing a research grant.

** Professor of Law, University of Nebraska College of Law. LL.M., George Washington University National Law College; J.D., University of South Dakota; B.S., Morningside College. I am grateful to Blake Carlile for his research efforts and to the University of Nebraska for providing a McCollum research grant. 
Coastal Council in which the Supreme Court endorsed the view that coastal areas are "valueless" in their natural state-a dangerous misconception laid bare by the post-Katrina awareness that wetlands and barrier islands instead perform an invaluable flood-taming function. We conclude with suggestions for reform of federal flood hazard policy, the national flood insurance program, and the regulatory takings doctrine.

\section{TABLE OF CONTENTS}

INTRODUCTION: DOUBLE TAKES .................... 1473

I. PROLOGUE: THE RIVER AND ATTEMPTS AT CONQUEST ............................... 1475

A. The Mighty Mississippi ...................... 1475

B. The Mighty Government...................... 1478

II. ACT ONE: THE FLOOD OF $1927 \ldots \ldots \ldots \ldots \ldots \ldots \ldots . \ldots 1480$

A. The Flood ............................. 1480

B. The Aftermath: The Call for Federal

Leadership .............................. 1482

C. The Lessons: The Inadequacy of Engineered

Flood Control............................ 1486

1. Beyond Levees Only: The Need for Floodwater Storage and Broader Disaster Relief ............. 1486

2. Beyond Structural Solutions: The Need for Insurance................................. 1489

III. ACT TWO: THE FLOOD OF $1993 \ldots \ldots \ldots \ldots \ldots \ldots \ldots \ldots . \ldots 1492$

A. The Flood .................................. 1492

B. The Aftermath: Floodplain Building Boom ..... 1494

C. The Lessons: The Perverse Incentives of

Federally Subsidized Flood Insurance ......... 1495

1. Reforming the National Flood Insurance Program . 1495

2. Strategic Retreat from Floodplains ............... 1496

IV. ACT THREE: THE HURRICANES OF 2005 ........... 1498

A. The Hurricanes ............................... 1498

B. The Aftermath: The Absence of Leadership ..... 1503

C. The Lessons: The Inadequacy of Engineered

Flood Control, Again ....................... 1507

1. Unnatural Disasters............................. 1507

2. The Value of Healthy Wetlands ................ 1508

V. INTERMEZZO: THE PHENOMENON OF "DOUBLE

TAKES" ...................................... 1510

A. Taking One: A Century of Risk-Shifting

Subsidies .................................... 1511

B. TAking Two: Government CoMpensation for

Halting Risky Development ....................... 1513

VI. DENOUEMENT: A SECOND LOOK AT DOUBLE

TAKES ..................................... 1518

$\mathbf{R}$

$\mathbf{R}$

$\mathbf{R}$

R

R

R

R

$\mathbf{R}$

R

R

R

R

R

R

R

R

R

R

R

R 
A. Restricting Federal Subsidies for Floodplain

DEVElopMEnT ........................... 1518

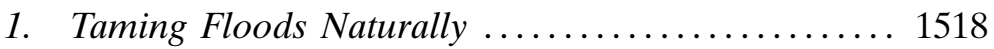

2. Insuring Wisely........................ 1523

B. Reforming the Regulatory Takings Doctrine .. 1530 EPILOGUE: CREATING A MANDATE FOR FEDERAL

LEADERSHIP .............................. 1534

\section{INTRODUCTION: DOUBLE TAKES}

THE flood hazard control system in the United States is broken, seemingly incapable of controlling flood waters or preventing loss of life and property. The statistics are sobering. Nine out of ten major natural disasters in the United States are flood-related, even though only seven percent of the nation's lands are considered floodplains. ${ }^{1}$ Since 1928 , the country has spent billions of dollars on flood control structures in coastal and floodplain areas, and flood insurance subsidies and benefit payments. ${ }^{2}$ Despite the massive expenditures, economic losses due to flooding have more than doubled during the same time period, currently approaching six billion dollars annually. ${ }^{3}$

The obvious question is what can be done to fix this broken system. But first, this Article asks, who are the victims of such flawed efforts at flood management? In the aftermath of any particular flood disaster, it is a relatively straightforward proposition to identify those who have died or suffered property damage. Too often, those who suffer most are the poorest members of society-those who lack either the ability to evacuate from a floodplain or the financial means to settle in less vulnerable areas. ${ }^{4}$ At other times, floods may strike expensive coastal resort property. ${ }^{5}$ However, to provide a more nuanced and systematic answer to this preliminary question, this Article adds a generally overlooked factor to the mix: the regulatory takings doctrine.

1. Saul Jay Singer, Flooding the Fifth Amendment: The National Flood Insurance Program and the "Takings" Clause, 17 B.C. Envtl. Aff. L. Rev. 323, 325 (1990).

2. The Corps alone has spent over $\$ 120$ billion (in 2002 dollars) on flood control in just the past twenty-five years. Gerald E. Galloway, Jr., Corps of Engineers Responses to the Changing National Approach to Floodplain Management Since the 1993 Midwest Flood, J. of Contemp. Water Res. \& Educ., Mar. 2005, at 5, 5. See Comprehensive and Integrated Approach to Meet the Water Resources Needs in the Wake of Hurricanes Katrina and Rita; Hearing Before the S. Comm. on Env'l \& Pub. Works, 109th Cong., (2005) (statement of Scott Faber), available at http://www.senate.gov/hearing_statements.cfm?id=219920 ("Because so many Corps flood control projects induce development in harm's way, flood damages have more than tripled in real dollars in the past 80 years-even as the Corps has spent more than $\$ 120$ billion on flood control projects.").

3. Adam F. Scales, A Nation of Policyholders: Governmental and Market Failure in Flood Insurance, 26 Miss. C. L. Rev. 3, 6 (2006-07); Sara Shipley, A Flood of Development: 10 Years Later, ST. Louis Post-Dispatch, July 27, 2003, at A8.

4. See infra notes 78, 199-200, 271-78, 360-61, and accompanying text.

5. See infra Part V.B. 
Setting forth what we call the theory of "double takes," this Article argues that taxpayers also shoulder significant economic loss under the current system. That is, federal law and policy have allowed floodplain developers to "take" resources from taxpayers through two critical mechanisms. First, if states and local communities forbid risky construction in floodplains and along coastlines, they may be judged liable for regulatory takings under the Fifth Amendment and be forced to provide compensation to would-be developers. Second, not only are taxpayers discouraged from prohibiting such development, but they actually subsidize it ex ante through the construction of federal flood control structures and ex post through the payment of federal flood insurance benefits and disaster relief. At times, the subsidies are cumulative, where the same tract of land qualifies for more than one subsidy, or, in the case of "repetitive loss," where the same structure is built time and again with insurance proceeds awarded after loss through flooding. Taxpayers ultimately hold the political clout to reform the system, and they may be important partners in managing flood hazards effectively and minimizing future human tragedy.

We explore the double takes theory through three stories involving the Mississippi River, which has served as "the crucible of U.S. flood policies." We come to this project with the passion of two natives of the Mississippi River basin. One of us grew up in St. Louis, near the confluence of the Mississippi and Missouri Rivers. This author recalls summer Sunday drives into the "river bottoms" to buy sweet corn and tomatoes directly from farm stands. ${ }^{7}$ The black, rich soil produced crops with unrivaled flavor. Today, much of the floodplain is occupied by "big box" stores, with construction booming on the very same site that suffered devastating flooding in 1993. ${ }^{8}$ The second author is from a farm near Sioux City, Iowa, situated on the banks of the Missouri River, the Mississippi's longest tributary. Her summers were punctuated by the rhythms of farm life: planting, cultivating, and harvesting corn and other crops. On weekends, her family enjoyed boating, camping, and fishing on the Missouri, where she quickly learned to appreciate the power, the beauty, and the ephemeral nature of the river's current, its sandbars, and its ever-shifting banks.

Taking our cue from the rivers of our childhoods, this Article aims to be broad and panoramic, reflecting on the lessons that emerge from flood disasters spanning nearly one century and more than two thousand miles. Part I provides a prologue to the Mississippi River stories, paying homage to the sheer natural force of the river, juxtaposed against the determined human will to control the river. Although flooding has been a recurrent phenomenon on the Mississippi River, three events stand out in terms of

6. Rutherford H. Platt, Review of Sharing the Challenge: Floodplain Management into the 21st Century, ENv'T, Jan.-Feb. 1995, at 25, 25.

7. This author also learned to drive-a stick-shift car, in those days-in the river bottom because of its long, flat roads and virtual lack of traffic. Today, shoppers clog some of its roads as they drive from one strip mall to another.

8. See infra Part III.B. 
both their physical and political magnitude: the Great Mississippi Flood of 1927, the Midwest Flood of 1993, and Hurricane Katrina in 2005. These three stories are the subject of Parts II through IV, which describe the floods and their aftermaths. This discussion also derives specific lessons from each of the floods, exposing the failure of federal leadership, as manifested through the inadequacy of federal flood control structures and the perverse incentives created by federal flood insurance. Parts V and VI offer a broader perspective, synthesizing the three flood stories into global lessons. This analysis calls for a bold response to the double takes phenomenon, including diminishment of federal subsidies-both physical and financial-for high-risk floodplain and coastal development, and reform to the regulatory takings doctrine. Overall, these reforms would serve to prevent the externalization of the risks of unwise development through taxpayer-funded subsidies, providing a powerful incentive to retreat from the inhabitation of vulnerable areas.

\section{PROLOGUE: THE RIVER AND ATTEMPTS AT CONQUEST}

I do not know much about gods; but I think that the river

Is a strong brown god-sullen, untamed and intractable,

Patient to some degree, at first recognised as a frontier;

Useful, untrustworthy, as a conveyor of commerce;

Then only a problem confronting the builder of bridges.

The problem once solved, the brown god is almost forgotten

By the dwellers in cities-ever, however, implacable,

Keeping his seasons and rages, destroyer, reminder

Of what men choose to forget. Unhonoured, unpropitiated

By worshippers of the machine, but waiting, watching and waiting

....

-T.S. Eliot ${ }^{9}$

\section{A. The Mighty Mississippi}

The Seducer of La Salle, the Prize of Jefferson, the Paradise of Huck Finn . . . 10

9. T.S. Eliot, The Dry Salvages, in The Four Quartets 21, 21 (1943). Eliot published The Four Quartets individually between 1935 and 1942. Each of the poems is associated with one of the four elements-air, earth, water, and fire-and each considers the nature of time through literary and musical devices. Thomas R. Rees, The Orchestration of Meaning in T.S. Eliot's Four Quartets, 28 J. of Aesthetics And Art Criticism 63, 67 (1969).

10. David Hage \& D.W. Miller, Mississippi on the Mend, U.S. News \& World ReP. Aug. 22, 1994, at 50, 50. René-Robert de La Salle was the first explorer to travel the length of the Mississippi River. He named the entire basin "Louisiana" in honor of King Louis XIV and claimed it for France in 1682. Explorers of the Millennium, René Robert Cavalrer Sieur de la Salle, http://library.thinkquest.org/4034/lasalle.html (last visited Sept. 9, 2007). France relinquished its claim to President Thomas Jefferson in 1803. See Treaty Between the United States of America and the French Republic, U.S.-Fr., April 30, 1803, 8 Stat. 200 [hereinafter Louisiana Purchase Treaty]. 
The Mississippi River, known to the Ojibwe Indians as "Big River, Father of Waters,"11 is the largest river in North America, flowing 3,705 kilometers $(2,300$ miles) from its source at Lake Itasca in northern Minnesota to the subtropical Louisiana Delta. ${ }^{12}$ Along the way, the nation's "watery aorta" 13 traverses the mid-continental United States and the Gulf of Mexico coastal plain, draining all or parts of thirty-one statesabout forty percent of the land base of the continental United States. ${ }^{14}$ In some areas its floodplain - the strip of land beside the river typically inundated during high water ${ }^{15}$-is an expansive ten miles wide..$^{16}$

The Mighty Mississippi boasts the unhappy distinction of being one of the most heavily modified river systems in the world. ${ }^{17}$ Along most of the upper river, the United States Army Corps of Engineers maintains dozens of locks and dams between Minneapolis and St. Louis to promote commercial navigation. ${ }^{18}$ These structures have radically altered the natural features of the river and its floodplain, replacing rapids, falls, and eddies with a highly regulated "stairway of water."19 Meanwhile, thousands of acres of wetlands and uplands within the floodplain have been drained and leveed to promote agriculture and urbanization. ${ }^{20}$ In Iowa, for example, approximately ninety-eight percent of the state's entire stock of native wetlands has been lost. ${ }^{21}$

The lower Mississippi River flows from Cairo, Illinois, to the Gulf of Mexico, where it "splits like the toes of a bird's foot" at Head-of-Passes into numerous channels that empty into the Gulf. ${ }^{22}$ Although the lower Mississippi has not been dammed, it has been altered just as drastically.

11. See The Mississippi River in Minnesota, http://www.twincitiestours.com/info_mississippi_river.html (last visited July 21, 2007). The Ojibwe people once called it Messippi or Mee-zee-see-bee. Id.

12. See 1 U.S. Geological Survey, Status and Trends of the Nation's BiologICAL ResourCES 351 (1998), available at, http://www.nwrc.usgs.gov/sandt/Misisipi.pdf.

13. Isabel Wilkerson, Running Wild: The Mississippi Reclaims Its True Domain, N.Y. Times, July 18, 1993, § 4, at 1 .

14. U.S. Army Corps of Eng'rs, History of the Mississippi River and Tributaries Project, http://www.mvn.usace.army.mil/pao/bro/misstrib.htm (last visited Sept. 8, 2007). The basin covers over 1.2 million square miles, which is about five times the size of the state of Texas. U.S. States (plus Washington D.C.): Area and Ranking, http://www.enchantedlearning.com/usa/states/area.shtml (last visited July 9, 2007).

15. Dept. of Reg'l Dev. and Env't Executive Secretariat for Econ. and Soc. Affairs Org. of Am. States, Primer on Natural Hazard Management in Integrated Regional Development Planning, ch. 8 (1991), available at http://www.oas.org/dsd/publications/Unit/oea66e/begin.htm\#Contents [hereinafter PRIMER ON NATURAL HAZARD Management].

16. John Tibbetts, Waterproofing the Midwest, Plan., Apr. 1994, at 8, 13 (quoting Richard Sparks, Director, Illinois Natural History Survey's River Research Laboratory).

17. U.S. Geological Survey, supra note 12, at 351-52.

18. See U.S. Army Corps of Eng'rs, Mississippi River Navigation, http://www. mvn.usace.army.mil/pao/history/MISSRNAV/federal.asp (last visited Sept. 8, 2007). See infra notes 35-39 and accompanying text (providing details about the Corps).

19. U.S. Geological Survey, About the Upper Mississippi River System, http://www. umesc.usgs.gov/umesc_about/about_umrs.html (last visited Sept. 5, 2007).

20. See id.

21. U.S. Geological Survey, Current Research, http:/www.umesc.usgs.gov/terrestrial/ amphibians/armi/current_research.html (last visited Sept. 8, 2007).

22. U.S. Geological Survey, supra note 12 , at 355. 
Over 120 river miles have been lost to channelization and straightening, and over eighty percent of the river's floodplain has been sacrificed to levee construction. ${ }^{23}$ These levees, which extend along both sides of the river's banks for nearly 1,700 miles, encase the lower river and its floodplain in a veritable strait-jacket. ${ }^{24}$ As a result, the area of seasonally flooded wetlands in the floodplain has been significantly reduced. ${ }^{25}$ Wetlands loss and deforestation to clear fields and promote urbanization have in turn resulted in an array of adverse environmental effects, including reduced flood water retention. ${ }^{26}$

As on many rivers, seasonal floods are natural, life-giving occurrences on the Mississippi River. Periodic flooding allows the river to deposit rich soils outside its channel and supports some of Earth's most diverse ecologic systems. ${ }^{27}$ Long before settlers began to build towns and clear fields along the river, American Indians and European explorers provided testimonials of periodic flooding. One of the earliest written accounts is from Garcilaso de la Vega, a member of the Hernando de Soto expedition, the first European expedition to document a discovery of the Mississippi River. ${ }^{28}$ In his journal, dated 1543, de la Vega described the flooding Mississippi as "mov[ing] swiftly out over some immense strands that lay between the main channel and its cliffs ... [and rising] gradually to the tops of these cliffs[;] . . . the river entered the gates of the little village of Aminoya in the wildness and fury of its flood, and two days later one could not pass through the streets of this town except in canoes." 29

Frequent floods on the Mississippi River have continued into modern times. In spite of humankind's best engineering efforts, the river occasionally flexes its muscles and escapes its banks, gobbling up everything in its path: sometimes it takes a hurricane to provoke this behavior; sometimes it just takes rain. Much of the lower Mississippi Valley was inundated in $1849 .{ }^{30}$ Major floods recurred every decade or so thereafter,

23. Id.

24. See id.

25. See, e.g., id. See also U.S. Envtl. Prot. Agency, Background on Lower Mississippi River Basin, http://www.epa.gov/msbasin/subbasins/lower/ (last visited Sept. 8, 2007) (stating that between 1950 and 1976, one-third of the lower Mississippi's bottomland forests was cleared and converted to agriculture; by 1980, only twenty percent of the original forested wetlands were left).

26. See U.S. Envtl. Prot. Agency, supra note 25.

27. Nat'l Park Serv., Mississippi (and other) River Information, http://www.nps.gov/ archive/miss/features/misshist/intro.html (last visited Sept. 10, 2007) ("Floodplain ecologies are some of the most diverse on the planet. [The Mississippi River's] unique seasonal cycles coincide with spawning habits and reproduction habits of plants and animals.").

28. See U.S. Army Corps of Eng'rs, supra note 14.

29. Am. Journeys, Eyewitness Accounts of Early American Exploration and Settlement, http://www.americanjourneys.org/teachers/geography.html (last visited May 23, 2007). See Russell E. Bearden, Arkansas' Worst Disaster: The Great Mississippi Flood of 1927, 34 Ark. Rev.: A Journal of Delta Studies 79, 80 (2003) (describing early accounts of the river's destructive force).

30. John M. Barry, Rising Tide: The Great Mississippi Flood of 1927 and How it Changed America 34 (1997) [hereinafter Barry, Rising Tide]. 
through 1993. ${ }^{31}$ Hurricanes wreaked havoc on the Mississippi River Delta, most notably in 1965 and 2005. ${ }^{32}$ The stories of affected floodplain communities, and the government's misguided efforts to conquer the river, are best portrayed by the floods and hurricanes of 1927, 1993, and 2005.

\section{B. The Mighty Government}

Not long after the U.S. Constitution was ratified, the federal government began to develop navigable waters under the premise that "rivers best serve society if they are controlled, diverted, and dammed." 33 The United States was determined to secure its Manifest Destiny-"an integrated nation that stretched from sea to sea"-by taming the nation's water resources for navigational purposes. ${ }^{34}$

The first federal agency to become involved in water affairs was the Corps of Engineers, which traces its history back to 1775 when the Continental Congress appointed a Chief of Engineers for the Continental Army under General George Washington. ${ }^{35}$ The original Corps was the military's engineering and construction arm until the close of the Revolutionary War in $1783 .{ }^{36}$ Congress re-established the Corps within the U.S. Army in $1802 .{ }^{37}$ The Corps' primary mission, then and now, "is to support the nation's fighting force." 38

To further the federal government's ambitious goals, the Corps of Engineers' mission grew to encompass navigational enhancement. ${ }^{39}$ In the 1820 s, at the direction of Congress, the Corps conducted a thorough investigation of the navigational capabilities and physical characteristics of the Mississippi and Ohio Rivers, and Congress passed legislation requiring the removal of snags and other obstructions from the channels of the rivers. ${ }^{40}$ The Supreme Court affirmed Congress' power to regulate navigation in 1824 in Gibbons v. Ogden, ${ }^{41}$ contrary to the prevailing sentiment at the time favoring local governance. ${ }^{42}$ Critics read Gibbons narrowly, believing that the central government had little authority be-

31. Id. at 158; U.S. Army Corps of Eng'rs, supra note 14.

32. NOAA's Nat'l Weather Serv. Forecast Office, The Mississippi River FLOOD OF 1967, http://www.crh.noaa.gov/arx/events/missflood_1965.php.

33. Daniel McCool, The River Commons: A New Era in U.S. Water Policy, 83 Tex. L. REV. 1903, 1903 (2005).

34. Donald Pisani, Water and American Government xii-xiii, 272-273 (2002).

35. U.S. Army Corps of Eng'rs, Brief History: The Beginnings to 1815, http://www. hq.usace.army.mil/history/brief.htm\#1beg (last visited Sept. 10, 2007).

36. See id.

37. See id.

38. E.R. Heiberg III, A Corps Chief Looks at Rising Tide, Civ. EnG'G, Feb. 1998, at 54, 55 (reviewing John Barry, Rising Tide: The Great Mississippi Flood of 1927 AND How It Changed America (1997)).

39. A. Dan Tarlock, A First Look at a Modern Legal Regime for a "Post-Modern" United States Army Corps of Engineers, 52 U. KAN. L. REv. 1285, 1285, 1299, 1301 (2004).

40. Mississippi River Navigation, supra note 18.

41. 22 U.S. (9 Wheat.) 1, 239-40 (1824).

42. PisAni, supra note 34 , at 253. 
yond the sphere of navigation, and that it lacked the authority to shield private property from flooding. ${ }^{43}$

Around the same time, the newly minted state legislatures of Louisiana (achieving statehood in 1812) 44 $^{4}$ and Mississippi (achieving statehood in $1817)^{45}$ created specialized units of local government to coordinate flood control activities across parish or county lines. ${ }^{46}$ These units were authorized to establish levee districts, to appoint inspectors to plan levees and drainage ditches for each district, and to inform landowners within the floodplain that they were expected to conduct some of the necessary construction work. ${ }^{47}$ The inspectors were also authorized to impose fines upon landowners who neglected their flood control duties and to conscript their slaves to build berms and levees. ${ }^{48}$

In 1861, Captain A.A. Humphreys and Henry Abbott issued their nowfamous Report Upon the Physics and Hydraulics of the Mississippi River; Upon the Protection of the Alluvial Region Against Overflow; and Upon the Deepening of the Mouths. ${ }^{49}$ This report contemplated only a narrow role for the federal government. It dictated the Corps' so-called "levees only" policy of navigation and flood control, which continues to influence modern-day river management. ${ }^{50}$ The "levees only" theory rests upon the assumption that as the quantity of water in a river increases-constrained by levees - the current will accelerate, providing sufficient force to scour the riverbed and deepen the river. ${ }^{51}$ As a result, the policy concludes, navigation will be enhanced and, in theory, no other flood control devices will be needed to direct water away from farms and structures in the floodplain. ${ }^{52}$

By 1880, the federal government had constructed miles of levees along the Mississippi River for navigational purposes, along with a thirty-foot deep shipping canal to the Gulf of Mexico. ${ }^{53}$ At that time, Congress stipulated that no federal money could be used to protect land from flooding

43. Id.

44. 7 The New Encyclopedia Britannica 511 (15th ed. 1993).

45. 8 The New Encyclopedia Britannica 188 (15th ed. 1993).

46. PISANI, supra note 34 , at 249.

47. Id.

48. Id.

49. Mississippi River Navigation, supra note 18.

50. See John M. Barry, After the Deluge: As Hurricane Katrina Made Clear, the Lessons of the Mississippi Flood of 1927 (Which Made Herbert Hoover President) Have Yet to Be Learned Smithsonian, Nov. 2005, at 114, 115 [hereinafter Barry, After the Deluge]; John McPhee, The Control of Nature 8, 11 (1989).

51. See Barry, After the Deluge, supra note 50, at 115.

52. Id. at 155 .

53. BARRY, Rising TIDE, supra note 30, at 89. This shipping canal occupies the South Pass. Id. at 76. A second route to the Port of New Orleans, completed in the 1950s, is known as the Mississippi River-Gulf Outlet Canal, a sixty-six mile channel that extends northwest from deep water in the Gulf of Mexico to the Inner Harbor Navigation Canal at New Orleans. Military, Port of New Orleans, http://www.globalsecurity.org/military/facility/new-orleans-port.htm (last visited July 29, 2007). 
or for any purpose other than navigation. ${ }^{54}$ Almost four decades later, Congress relented somewhat through the Flood Control Act of 1917,55 the first federal enactment that explicitly appropriated money for river improvements other than navigation. It allocated $\$ 45$ million for flood control work between the mouth of the Ohio and the mouth of the Mississippi. ${ }^{56}$ The project was supervised by the Mississippi River Commission, an entity comprised of Corps officials, a representative of the U.S. Geological Survey, and a few civilian members. ${ }^{57}$ Local entities were required to secure the necessary rights-of-way for levees and to contribute one-half of the cost of levee construction. ${ }^{58}$

By the 1920s, massive walls of earth eighteen feet high stretched more than 1,800 miles along the lower Mississippi River. ${ }^{59}$ As immense as they seemed, these levees were no match for the 1927 flood.

\section{ACT ONE: THE FLOOD OF 1927}

\section{A. The FLOOD}

April is the cruellest month.

In the late winter and spring of 1927, rain fell in sheets in the lower Mississippi basin. ${ }^{61}$ Five separate storms rolled through, each one greater than anything residents had experienced before. ${ }^{62}$ On Good Friday, rain pummeled a 100,000 square mile area from Illinois all the way to the Gulf. ${ }^{63}$ New Orleans broke all existing records for the area-fifteen inches of rain in eighteen hours. ${ }^{64}$

The first major crevasse in the government levees occurred on April 16, 1927, near Dorena, Missouri, thirty miles south of Cairo, Illinois. ${ }^{65}$ Over 1,000 feet of the levee crumbled in the face of the raging flood waters. ${ }^{66}$ Author John Barry provides a vivid description of the event:

54. PISANI, supra note 34, at 253; A Brief Chronology of What Congress Has Done Since 1824 to Control the Floods of the Mississippi, 7 Cong. Digest 44, 44 (1928) [hereinafter A Brief Chronology].

55. Pub. L. No. 64-367, 39 Stat. 948 (1917).

56. See id.

57. A Brief Chronology, supra note 54 , at 44 . The Commission was created by congressional enactment in 1879. Id. From the start, it was dominated by the Corps, so much so that a former Chief of Engineers for the Corps referred to it as "its Mississippi River Commission." Heiberg, supra note 38, at 54 (emphasis added).

58. A Brief Chronology, supra note 54, at 45.

59. PISANI, supra note 34, at 250.

60. T.S. Eliot, The Waste Land (1922), in T.S. Eliot: Collected Poems, 1909-1962, at $53,53(1970)$.

61. Barry, After the Deluge, supra note 50, at 115.

62. $I d$.

63. Id.

64. Id. at 114 .

65. See BARRY, Rising TIDE, supra note 30, at 194.

66. Id. 
The river poured through the breach, tearing down trees, sweeping away buildings, and destroying faith . . . . The Mississippi was three miles wide between the levees, darker and thicker and more wild than any man, red, black, or white, had ever seen it. Detritus of the flood-tree branches and whole trees, part of a floor, a roof, the remains of a chicken coop, fence posts, upturned boats, bodies of mules and cows-raced past. ${ }^{67}$

A few days later, on April 21, a far more serious breach opened at Mounds Landing, Mississippi. ${ }^{68}$ Workers, many of them conscripted from the plantations at gunpoint, hefted sandbags to the top of the levee as the river threatened to pour over. ${ }^{69}$ The river swept the sandbags away as quickly as they were laid:

Under their feet the levee quivered, shook .... The roar of the crevasse drowned all sound. It carried up and down the river for miles, carried inland for miles. It roared like some great wild beast proclaiming its dominance ... . The Memphis Commercial-Appeal said, "Thousands of workers were frantically piling sandbags . . . when the levee caved. It was impossible to recover the bodies swept onward by the current at an enormous rate of speed." 70

The break widened until a 100 -foot wall of water nearly a mile wide cascaded over the Delta. ${ }^{71}$ Within just ten days, one million acres were flooded with water ten feet deep, and water continued to flow through the gap for months. ${ }^{72}$

In all, the levees ruptured in 145 places. ${ }^{73}$ The flood lasted for two months and covered nearly seventeen million acres in seven states. ${ }^{74}$ At its widest point, just north of Vicksburg, Mississippi, the swollen river formed an "inland sea nearly 100 miles across."75

The Red Cross and private volunteers conducted valiant rescue operations. ${ }^{76}$ For its part, the U.S. military provided seaplanes from Pensacola Naval Air Station for daily reconnaissance missions to inspect levees, locate refugees, map out appropriate rescue routes for watercraft, and provide food and medical supplies. ${ }^{77}$ In many cases, however, black workers and refugees were denied evacuation services and cut off from supplies by plantation owners and overseers. ${ }^{78}$

The flood caused over $\$ 200$ million in property damage (about $\$ 2$ bil-

67. Id. at $194,196$.

68. PISANI, supra note 34, at 250.

69. BARRY, RISING TIDE, supra note 30 , at 200-01.

70. Id. at $200-02$.

71. Id. at 201-02.

72. Id. at $202-03$.

73. City of Clarendon, AR, Where We've Been: 1927 Flood, http://www.clarendonar.com/been/flood/index.html (last visited Sept. 20, 2007).

74. Id.

75. Barry, After the Deluge, supra note 50, at 116.

76. Bearden, supra note 29 , at 85,88 .

77. Id. at 89 .

78. $I d$. 
lion in 2000 dollars). ${ }^{79}$ The three hardest-hit states were Arkansas, Mississippi, and Louisiana. ${ }^{80}$ Arkansas claimed to have suffered the most extensive property damage, with over two million acres of agricultural lands and nearly 60,000 houses inundated. ${ }^{81}$ Mississippi experienced the highest death toll. ${ }^{82}$ "[O]fficially, the [federal] government said 500 people died, but a disaster expert who visited the flooded area estimated that more than 1,000 perished in . . . Mississippi alone."83 Hundreds of thousands of survivors displaced by the flood took up residence at Red Cross encampments; many of them remained for over six months. ${ }^{84}$

\section{B. The Aftermath: The Call for Federal Leadership}

In spite of the limited media coverage available at the time-no twenty-four hour news networks and, indeed, no television at all-the 1927 flood penetrated to the nation's core. It marked a watershed moment when the fallacy of letting local governments and powerful individuals take the lead for water resources management-rescuing "Main Street with Main Street"-was laid bare. ${ }^{85}$ It shattered the myth of federal-state power distribution by causing the public to re-examine longstanding perceptions of the limited responsibilities of the federal government. ${ }^{86}$ Citizens cried out for federal leadership, technology, and financial resources to control floods and remediate their devastating effects. ${ }^{87}$ The U.S. Chamber of Commerce warned Congress that the federal government must undertake the necessary work, lest the country return to a "great waste extending from Cairo to the Gulf." 88

Flood control was the most pressing issue before the Seventieth Congress, which sat from 1927 to $1929 .{ }^{89}$ Congressional members quickly recognized that the problems were two-fold. First, Congressman Edward Denison of Illinois criticized the absence of federal leadership: "the Federal Government has allowed the people ... to follow their own course and build their own levees as they choose and where they choose until the action of the people of one State has thrown the waters back upon the people of another State, and vice versa."90 Moreover, as Congressman

79. United States v. James, 478 U.S. 597, 606 (1986) (citing S. REP. No. 70-619, at 12 (1928)). To convert 1927 dollars to 2000 dollars, see Fed. Reserve Bank of Minneapolis, What is a Dollar Worth, http://minneapolisfed.org/research/data/us/calc/ (last visited Sept. 5, 2007).

80. See Bearden, supra note 29 , at 86.

81. Id.

82. Id.

83. Barry, After the Deluge, supra note 50, at 115.

84. See PisAni, supra note 34 , at 250.

85. BARRy, Rising Tide, supra note 30, at 375 (quoting President Herbert Hoover).

86. Id. at 422 .

87. See id.

88. A Summary of the Mississippi River Commission's Recommendations for Control of Floods, 7 Cong. Digest 54, 54, 69-70 (1928).

89. James v. United States, 760 F.2d 590, 596 (5th Cir. 1985), rev'd, 478 U.S. 597 (1986) (citing 69 Cong. Rec. 5294 (1928) (statement of Sen. James Reed)).

90. PisAni, supra note 34 , at 252. 
Robert Crosser of Ohio noted, the federal government's "levees only" policy-a "monumental blunder"-was not the right sort of federal guidance: 91

Many millions of dollars have been spent in an effort to control floods in the Mississippi Valley. Most of the work has been worse than wasted, for it has done much harm instead of good .... We have spent many millions of dollars to build levees; that is, great embankments alongside of and a little distance from the natural banks of the river, and the result has been that every flood has been more disastrous than the floods which preceded it. ${ }^{92}$

Despite congressional zeal for reform, President Calvin Coolidge balked. He believed, as had most presidents before him, that the federal government should not be in the business of protecting people from acts of God, such as floods. ${ }^{93}$ "The Government is not an insurer of its citizens against the hazard of the elements," Coolidge remarked in his annual message to Congress. ${ }^{94} \mathrm{He}$ argued that local citizens must be charged with responsibility for the cost of flood control to ensure that they had a "pecuniary interest in preventing waste and extravagance."95

Proponents of a federal flood control package overcame Coolidge's resistance with provisions for state and local funding contributions. ${ }^{96}$ The damage to Coolidge's public image, however, could not be undone. Once the political logjam broke, Coolidge was swept out of office. ${ }^{97}$ Herbert Hoover, a "logistical genius" who had been placed in charge of the rescue and rehabilitation of nearly a million destitute people in the Mississippi River Valley, rode the wave all the way to the Oval Office. ${ }^{98}$

The bill that finally emerged, the Flood Control Act of 1928, declared that the federal government would take responsibility for the Mississippi

91. James, 760 F.2d at 597 (citing H.R. REP. No. 70-1072, at 7 (1928)). Colonel Heiberg, a former commander-in-chief of the Corps, conceded that the blame for foregoing floodways and retention basins in favor of "levees only" lies squarely at the Corps' feet. Heiberg, supra note 38, at 54. Heiberg added that "the strong desire of so many Americans to live, farm or work in the floodplain" exacerbated the devastation. Id. at 55.

92. James, 760 F.2d at 597 (citing 69 CONG. REC. 7011 (1928) (statement of Rep. Robert Crosser)). Crosser served as chairman of the Interstate \& Foreign Commerce Committee (1948-52) and the first congressional Flood Control Committee. Biographical Directory of the United States Congress, Robert Crosser, http://bioguide.congress.gov/ scripts/biodisplay.pl?index $=$ C000932 (last visited Sept. 15, 2007); The Encyclopedia of Cleveland History, http://ech.case.edu/ech-cgi/article.pl?id=CR10 (last visited Sept.15, 2007).

93. See PISANI, supra note 34 , at 251.

94. President Coolidge's Analysis of the Mississippi Flood Control Problem, 7 Cong. Digest 46, 46 (1928).

95. Id.

96. BARry, Rising TIDE, supra note 30 , at 406.

97. See id.

98. Barry, After the Deluge, supra note 50, at 116. Calvin Coolidge's presidency extended from 1923 to 1929, and Herbert Hoover's extended from 1929 to 1933. 3 THE New EnCyClopedia Britannica 600 (15th ed. 1993), 6 The New Encyclopedia Britannica 48 (15th ed. 1993). 
River. ${ }^{99}$ These responsibilities were primarily structural, requiring the construction of more federal levees and-importantly-also calling for the construction of spillways and reservoirs. ${ }^{100}$ At the same time, the Act immunized the federal government from any liability "of any kind ... for any damage from or by floods or flood waters at any place."101

By today's standards, the 1928 Act was a modest measure, but in fiscal terms it was more expensive than anything else the federal government had ever undertaken except World War I.102 The levees, reservoirs, and outlets authorized by the Act cost around $\$ 325$ million, ${ }^{103}$ four times the cost of the Panama Canal, which was completed in 1914. ${ }^{104}$ Even more importantly, by setting a precedent for widespread federal involvement in what had long been perceived as a purely local affair, the 1928 Act represented "a major shift in what Americans considered the proper role and obligations of the national government." 105

In passing the Flood Control Act of 1928, congressional members were influenced by Progressive Era objectives. Comprehensive planning and multiple-use management were hallmarks of the time. ${ }^{106}$ The goal was nothing less than a unified, planned society. ${ }^{107}$ In the early 1900s, many federal agencies, including the Bureau of Reclamation and the U.S. Geological Survey, had agreed that each river must be treated as an integrated unit from source to mouth. ${ }^{108}$ Rivers were to be developed "systematically and consistently," with coordination of navigation, flood control, irrigation, and hydro-power. ${ }^{109}$ But the Corps of Engineers refused to join the movement toward watershed planning, instead preferring to conduct river management in a piecemeal fashion for the benefit of myriad local interests. ${ }^{110}$ Interagency rivalries made comprehensive watershed planning all the more unlikely, in spite of congressional aspirations. ${ }^{111}$ According to environmental historian Samuel Hays: "A multiple-purpose water program collapsed ... as each interest group, seeking influence and power in resource management, obtained from Congress a

99. Pub. L. No. 70-391, 45 Stat. 534 (codified as amended at 33 U.S.C.A. $\$ \S 701-09$ (West 2006)).

100. Id.

101. United States v. James, 478 U.S. 597, 604 (1986) (citing 33 U.S.C.A. § 702 (emphasis added)). The terms "flood" and "flood waters" have been construed broadly to apply "to all waters contained in or carried through a federal flood control project for purposes of or related to flood control." Id. at 605. As a result, in United States v. James, claims against the United States for deaths of recreational boaters who drowned after being swept through open discharge gates of federal flood control reservoirs were dismissed. See id. at 597.

102. Barry, After the Deluge, supra note 50, at 120.

103. H.R. REP. No. 70-1101, at 13 (1928).

104. James, 478 U.S. at 606 (citing 69 Cong. Rec. 6640 (1928) (statement of Rep. Snell)).

105. BARRY, Rising TIDE, supra note 30 , at 407.

106. PISANI, supra note 34, at 285.

107. See id.

108. See id.

109. Id. at 285 .

110. Id. at 286 .

111. See id. 
special program for its particular concern, be it flood control, drainage, reclamation or navigation." 112 Localism overcame efficiency, and limited or single-purpose water projects, like levees, prevailed. ${ }^{113}$

After 1928, Congress passed a veritable deluge of Flood Control Acts. ${ }^{114}$ Each one added an additional layer to the complicated assortment of authorities for the construction and maintenance of flood control devices, and each one deviated further from the ideal of comprehensive watershed planning. ${ }^{115}$

The Flood Control Act of $1936^{116}$ is particularly notable because, for the first time, Congress explicitly recognized federal responsibility for flood control measures nationwide. Congress proclaimed that "destructive floods . ... upsetting orderly processes and causing loss of life and property, . . . constitute a menace to national welfare." 117 To control the menace, the 1936 Act delegates broad discretion to the Corps to construct any flood control project it chooses (so long as Congress agrees to appropriate the necessary funds). ${ }^{118}$ The Corps' discretion is constrained by only a malleable cost-benefit requirement, allowing the Corps to proceed whenever "the benefits to whomsoever they may accrue are in excess of the estimated costs." 119

Just as the Corps began erecting flood control structures throughout the nation under the auspices of the 1936 Act, the Missouri River rose up from its banks in 1942 and again in 1944 to claim towns and fields in its floodplain. ${ }^{120}$ The Flood Control Act of 1944 responded by authorizing five huge mainstream dams and reservoirs on the upper Missouri, in hopes of protecting the population centers and farms of the lower basin of the Missouri, and of the Mississippi River below the mouth of the Missouri River at St. Louis. ${ }^{121}$ Periodic flooding continued, however, dem-

112. Id. (quoting Samuel Hays).

113. Id.

114. BARRY, Rising TIDE, supra note 30, at 423.

115. See, e.g., Flood Control Act of 1936, Pub. L. No. 74-738, 49 Stat. 1570; Flood Control Act of 1944, Pub. L. No. 78-534, 58 Stat. 887; Flood Control Act of 1965, Pub. L. No. 89-298, 79 Stat. 1073 (codified at 33 U.S.C.A. $§ 701(\mathrm{e})$ ).

116. 33 U.S.C.A. § 701a (West 2001).

117. Id.

118. Id.

119. Id.

120. For details on Missouri River characteristics, history, and politics, see JoHN R. Ferrell, Big Dam Era: A Legislative and Institutional History of the PickSloan Missouri Basin Program (1993); Bill Lambrecht, Big Muddy Blues: True Tales and Twisted Politics Along Lewis and Clark's Missouri River (2005); Robert Kelley Schneiders, Unruly River: Two Centuries of Change Along the Missouri (1999); John E. Thorson, River Of Promise, River Of Peril: The Politics Of Managing The Missouri River (1994).

121. Flood Control Act of Dec. 22, 1944, Pub. L. No. 78-534, 58 Stat. 887 (codified in various provisions of Titles 16, 33 and 43 of the United States Code). Detailed accounts of the events that led to enactment of the Flood Control Act of 1944, also known as the PickSloan Act, are provided in Ferrell, supra note 120; MichaEl L. LAwsON, Dammed INDIans: The Pick-Sloan Plan and the Missouri River Sioux, 1944-1980 (1982); Thorson, supra note 120, at 63-67; and John H. Davidson \& Thomas Earl Geu, The Missouri River and Adaptive Management: Protecting Ecological Function and Legal Process, 80 
onstrating the folly of the government's single-minded reliance on structural devices.

\section{The Lessons: The Inadequacy of Engineered Flood Control}

This isn't a natural disaster. It's a manmade disaster. -Gifford Pinchot ${ }^{122}$

The 1927 flood convinced the nation that the existing flood control infrastructure-consisting of local flood control levees plus federal navigational levees-was no match for a major flood event. It convinced Congress that extensive federal intervention would be necessary to protect floodplain communities. As a result, Congress authorized the construction of a network of federal levees, not just for the purpose of aiding navigation, but specifically to prevent flooding. Moving beyond its "levees only" philosophy, Congress also authorized reservoirs, spillways, and other structural flood control devices to contain excess water overflowing the river's channel. The flood also propelled the federal government into the business of providing widespread relief to victims of natural disasters.

Only a few decades after the 1927 flood, the Mississippi River rose up out of its banks once again, teaching a new lesson: federal structural responses plus disaster relief pay-outs had incentivized ever more daring incursions into the floodplain. The floodwater evaded federal efforts to control it with engineered structures, and those same structures prevented the river from finding its natural retention areas-wetlands, oxbows, and meanders - that had previously provided safe storage for floodwater. The resulting damage to affected areas was increased by orders of magnitude. The federal response to this lesson was the adoption of a nationwide flood insurance program intended to discourage unwise floodplain development and to limit the need for disaster relief. Both lessons are detailed in this section.

\section{Beyond Levees Only: The Need for Floodwater Storage and Broader Disaster Relief}

Through the mid-1900s, water policies at all levels of government "reflected remarkably consistent attitudes toward nature."123 Natural resources were to be transformed into "predictable, manageable, and

Neb. L. ReV. 816, 827-34 (2001); John R. Guhin, The Law of the Missouri, 30 S.D. L. REV. 347, 354-57 (1985). For a critique of the 1936 and 1944 Acts and recommendations for change in Missouri River management, see Sandra B. Zellmer, A New Corps of Discovery for Missouri River Management, 83 NEB. L. REv. 305, 312-18 (2004).

122. Barry, After the Deluge, supra note 50, at 115 (quoting Gifford Pinchot, upon surveying the damage wrought by the 1927 flood). "Pinchot, the first chief of the U.S. Forest Service, is widely regarded as the father of utilitarian conservation policy." Robert B. Keiter, Public Lands and Law Reform: Putting Theory, Policy, and Practice in Perspective, 2005 Utah L. Rev. 1127, 1159.

123. PisAni, supra note 34, at 272. 
measurable units - as well as commodities that could be bought, sold and traded." 124 If anything, rather than humbling humankind before the forces of nature, the Great Mississippi Flood redoubled the determination to subdue the river. The federal government marshaled its forces as if preparing for battle.

With funding made available through the 1928, 1936, and 1944 Flood Control Acts, more and higher levees were constructed, specifically for flood control purposes. In addition to levees, dams and reservoirs were added to the mix. As U.S. cities struggled to adjust to a peacetime economy, however, officials of many midwestern cities viewed further industrial and urban development in the floodplains as crucial for maintaining the local tax base. ${ }^{125}$ The presence of federal levees and reservoirs lulled them into complacency about the risk of flooding.

Floods on the Missouri River in the 1940s consumed some of the new development, motivating Congress to enact a national disaster relief program. ${ }^{126}$ The federal government had been in the business of case-bycase disaster relief since 1815, when it granted 160-acre plots to residents of New Madrid (situated in the territory that became Missouri) to replace land damaged by earthquakes. ${ }^{127}$ In contrast, the Disaster Relief Act of 1950 authorized the President, upon the request of a state, to declare that a particular event constituted a major disaster and then direct federal agencies to provide aid to the victims. ${ }^{128}$ The Act maintained that disaster relief was a local responsibility, but recognized that some disasters were so devastating that relief was beyond the financial capabilities of local governments. ${ }^{129}$

The new flood control and disaster relief programs were put to the test when catastrophic flooding occurred on the Kansas River in eastern Kansas and the Missouri River in Missouri. Above-normal precipitation during the spring of 1951 had saturated the soil. ${ }^{130}$ When unprecedented amounts of rain continued to fall in July, flooding was inevitable. ${ }^{131}$

Kansas received the most media attention:

124. $I d$.

125. Steven L. Driever \& Danny M. Vaughn, Flood Hazard in Kansas City Since 1880, Geographical Rev., Jan. 1988, at 1, 12-13.

126. Disaster Relief Act of 1950, Pub. L. 81-875, 64 Stat. 1109.

127. James M. Wright, The Nation's Responses To Flood Disasters: A Historical Account: A Report by the Association of State Floodplain Managers 67 (2000), available at http://www.floods.org/PDF/hist_fpm.pdf. The New Madrid Earthquake of 1812 remains the largest earthquake ever recorded in the continental United States, with an estimated magnitude of 8.0 on the Richter scale. Gaines M. Foster, The Demands of Humanity: Army Medical Disaster Relief 12 (2005), available at http:/history. amedd.army.mil./booksdocs/misc/disaster/frameindex.html (Ch. 2, The Nineteenth Century: Precedents).

128. Disaster Relief Act of $1950 \S \S 2$ (a), 3.

129. Wright, supra note 127, at 68-69 (citing Elliot Mitler, A Fiscal Responsibility Analysis of a National Earthouake Insurance Program 19 (1992)).

130. Kyle E. Juracek et al., U.S. Geological Soc'y, The 1951 Floods in Kansas REVISITED 2 (2001), available at http://ks.water.usgs.gov/Kansas/pubs/fact-sheets/fs.041-01. pdf.

131. Id. at 1 . 
[T]ransportation was disrupted as highways and railroads were closed from days to weeks. Damage to municipal water supplies and sewage-treatment works was also extensive. In Kansas, 33 watersupply systems were shut down, requiring that water be brought to the affected communities by tank trucks. At Topeka, the water works were kept in operation thanks to the efforts of as many as 5,000 men at a time that maintained a floodwall during the flood. One of the more unusual damage reports came from Le Roy, Kansas, where the Neosho River had washed caskets from graves at the Le Roy Cemetery. ${ }^{132}$

From the headwaters of the Kansas River to the mouth of the Missouri River at St. Louis, two million acres were flooded, forty-five thousand homes were damaged or destroyed, and seventeen major bridges were washed away. ${ }^{133}$ Estimates of the total damage were as high as $\$ 2.5$ billion (about $\$ 17$ billion in 2000 dollars). ${ }^{134}$ The American Red Cross reported nineteen flood-related deaths and one thousand injuries. ${ }^{135}$

The 1951 flood stimulated the construction of additional flood-control reservoirs, dams, and levees on the Kansas and Missouri Rivers. ${ }^{136}$ Ironically, the 1951 flood spawned a measure of indifference to floodplain protection elsewhere. In Kansas City, for example, development pressures simply shifted to the Blue River floodplain. ${ }^{137}$ Far from resisting further development of the floodplain, local officials actively assisted industrial expansion to accommodate General Motors, Sheffield Steel, and other industries. ${ }^{138}$

The very next year, the Missouri River emerged from its banks once again, claiming vast portions of the floodplain between St. Joseph, Missouri, and Sioux City, Iowa. The 1952 flood remains the greatest flood of record for Omaha, Nebraska, and other locations along the Missouri River. ${ }^{139}$ The entire city of South Sioux City, Nebraska, with its nearly 6,000 residents, was urged to evacuate as dikes protecting the city failed. ${ }^{140}$ One-third of the city was flooded to a depth of eight feet. ${ }^{141}$ Evacuation orders were also issued for 30,000 residents of Council Bluffs, Iowa, and 40,000 residents of Carter Lake, Iowa, and East Omaha, Nebraska. ${ }^{142}$ When President Truman visited Omaha to see the flooding, he immediately declared it a disaster area. ${ }^{143}$ Nearly 1,400 houses and

132. Id. (citations omitted).

133. Id.

134. Id.

135. Id.

136. Id. at 2; Walter M. Kollmorgen, Settlement Control Beats Flood Control, Econ. GeOGRAPHy, July 1953, at 208, 209.

137. Driever \& Vaughn, supra note 125, at 12-13.

138. Id.

139. Neb. Dep't of Natural Res., Historic Floods on the Missouri River, http://www. dnr.ne.gov/floodplain/mitigation/mofloods.html (last visited Sept. 10, 2007).

140. Id.

141. Id.

142. $I d$.

143. $I d$. 
200,000 agricultural acres were inundated. ${ }^{144}$ The Corps' preliminary estimate of economic damages was $\$ 12$ million (about $\$ 78$ million in 2000 dollars), but this figure likely overlooked some aspects of the flood damage, such as infrastructure losses and business interruption. ${ }^{145}$

\section{Beyond Structural Solutions: The Need for Insurance}

\section{Thou shalt not hinder the waters of inundation. ${ }^{146}$}

Paradoxically, navigational structures and floodplain constriction by levees, highway embankments, and development projects exacerbated the flood damage all along the rivers in 1951 and 1952. ${ }^{147}$ Flood-control engineering works not only enhanced the danger of floods, but actually contributed to higher flood losses. Flood losses were, in turn, used to justify more extensive control structures, creating a vicious cycle of everincreasing flood losses and control structures. ${ }^{148}$ The mid-century floods demonstrated the need for additional risk-management measures.

In the wake of the 1951 flood, President Truman recommended that $\$ 50$ million be set aside for a federally subsidized insurance program. ${ }^{149}$ Truman's initial proposal was killed, in part, by the private insurance industry's lobbyists. ${ }^{150}$ In 1952, President Truman tried again, this time asking for $\$ 1.5$ billion for flood insurance to be administered by private industry. ${ }^{151}$ It took more than a decade, however, for Congress to provide a meaningful response.

In 1956, President Eisenhower floated a proposal for a $\$ 3$ billion flood insurance program. ${ }^{152}$ The Eisenhower plan had a "new wrinkle," in that forty percent of the premiums would be subsidized by a state-federal partnership. ${ }^{153}$ Congress was persuaded to pass the Flood Insurance Act of $1956,{ }^{154}$ but funds were never appropriated for its implementation, in large part due to fears that, rather than limiting losses, the availability of subsidized insurance would cause further development in the floodplains

144. $I d$.

145. Id. To convert 1952 dollars to 2000 dollars, see Fed. Reserve Bank of Minneapolis, supra note 77.

146. Nova: Flood! (PBS television broadcast May 6, 1997) (transcript available at http:// www.pbs.org/wgbh/nova/transcripts/2307tfloo.html) (statement of Scott Faber, Senior Director of Public Policy for American Rivers, quoting from THE BoOK OF THE DEAD).

147. Richard E. Sparks \& Ruth Sparks, After Floods: Restoring Ecosystems, USA ToDAy (Society FOR THE Advancement of EDUCATION), July 1, 1994, at 40.

148. Kollmorgen, supra note 136, at 210.

149. Oliver A. Houck, Rising Water: The National Flood Insurance Program and Louisiana, 60 Tul. L. REv. 61, 67 (1985); Singer, supra note 1, at 334.

150. Singer, supra note 1 , at 334 .

151. Id. at $334-35$.

152. Id. at 335 .

153. Id.

154. Pub. L. No. 84-1016, 70 Stat. 1078, repealed by Pub. L. No. 90-448, 82 Stat. 573; American Institute for Research et al., A Chronology of Major Events Affecting the National Flood Insurance Program 6 (2002), available at http://www. dhs.gov/xlibrary/assets/privacy/privacy_pia_mip_apnd_h.pdf. 
and lead to even greater flood damage. ${ }^{155}$

Interest in flood insurance and other non-structural risk management tools was renewed by a series of natural disasters in the early 1960s. ${ }^{156}$ Federal agencies were ordered to evaluate the risks of flooding before acquiring federal property or releasing funds for construction in floodplains. ${ }^{157}$ Meanwhile, Congress directed the Department of Housing and Urban Development to prepare a report on insurance as one component of a mix of disaster relief and flood control measures. ${ }^{158}$

Renowned geographer Gilbert White, known as the "father of floodplain management," chaired a task force commissioned to reexamine the nation's flood control policies. ${ }^{159}$ The 1966 Report of the Task Force on Federal Flood Control Policy emphasized "multiple adjustments," 160 which meant that, in addition to levees and other conventional structural controls, land-use restrictions, forecasting, and warning systems should also be part of the nation's flood management strategy. ${ }^{161}$ It also recommended a federal flood insurance program, but with an admonition reminiscent of the concerns voiced by Congress in 1956: "A flood insurance program is a tool that should be used expertly or not at all. Correctly applied, it could promote wise use of flood plains. Incorrectly applied, it could exacerbate the whole problem of flood losses."162 Gilbert's warning would prove to be remarkably accurate.

Two years later, the National Flood Insurance Act finally became law in Title XIII of the Housing and Urban Development Act of 1968. ${ }^{163}$ The Act establishes a joint private/government flood insurance program, known as the National Flood Insurance Program ("NFIP"). ${ }^{164}$ Among other things, the NFIP was intended to pressure local governments to adopt land-use control measures to promote "rational use of the flood plain." 165 It was also intended to defray the after-the-fact expense of federal disaster relief by encouraging floodplain occupants to pay premiums before disaster struck. ${ }^{166}$ These goals were to be accomplished through a type of quid pro quo arrangement: the federal government would offer

155. Singer, supra note 1, at 334-35 n.50.

156. See infra notes $244-47$ and accompanying text.

157. Singer, supra note 1 , at 335 .

158. Id.

159. Platt, supra note 6, at 26. White is known for advocating accommodation of flood hazards rather than structural solutions (dams and levees) wherever feasible. Gilbert F. White: A Short Biography, http://www.colorado.edu/hazards/gfw/bio.html (last visited July 30, 2007).

160. Comm. on Flood Control Alternatives in the Am. River Basin, Water Sci. \& Tech. Bd., Flood Risk Management and the American River Basin: An EvaluATION 164 (1995).

161. Platt, supra note 6 , at 25 .

162. Gilbert F. White-Vita, http://www.colorado.edu/hazards/gfw/vita.html (last visited Sept. 11, 2007).

163. 42 U.S.C.A. $\S \S 4001-4129$ (West 2000).

164. Platt, supra note 6 , at 25.

165. S. ReP. No. 93-583 (1973), as reprinted in 1973 U.S.C.C.A.N. 3217, 3219.

166. Platt, supra note 6, at 26. See Christine M. McMillan, Comment, Federal Flood Insurance Policy: Making Matters Worse, 44 Hous. L. Rev. 471, 476 (2007) (describing 
insurance to residents at below-cost rates in exchange for the adoption of appropriate land use and other restrictions by community officials. ${ }^{167}$

To qualify for the NFIP, a community must adopt ordinances to regulate future development in Special Flood Hazard Areas ("SFHAs"), 168 which are areas determined to be within the 100-year floodplain-a standard that would later prove to be disastrously inadequate. ${ }^{169}$ The ordinances must meet minimum criteria established by the Federal Emergency Management Administration ("FEMA"), including zoning restrictions, building requirements, flood control projects, flood-proofing, hazard mitigation plans, and emergency preparedness plans. ${ }^{170}$ The most common community responses include the adoption of construction and building codes and construction bans in the immediate floodway. ${ }^{171}$ Federally subsidized insurance is available to properties that already existed at the time the area was identified as a SFHA, even if the community fails to regulate future development in the hazard area. ${ }^{172}$ The government estimated that the turnover in housing stock would require premium subsidies for twenty-five years, but as of 2006, nearly thirty percent of NFIP policies were still subsidized. ${ }^{173}$

Only five years after the program was enacted, Gilbert White's admonition was validated. Congress found that flood losses were continuing to increase due to the accelerating development of floodplains. Ironically, both federal flood control infrastructure and the availability of federal flood insurance were at fault. ${ }^{174}$ To address the problem, Congress passed the Flood Disaster Protection Act of 1973, which made federal assistance for construction in flood hazard areas, including loans from federally insured banks, contingent upon the purchase of flood insurance, which is only made available to participating communities. ${ }^{175}$

seven specific goals intended to accomplish the overarching purpose of "providing insurance and creating appropriate land use policies in flood-prone areas").

167. Singer, supra note 1 , at 323 .

168. 42 U.S.C.A. $\S \S 4101-02$ (West 2002); 44 C.F.R. $\$$ 65.1-.3 (2006).

169. Fed. Emergency Mgmt. Agency, National Flood Insurance Program DESCRIPTION (2002), available at http://www.fema.gov/doc/library/nfipdescrip.doc. See also infra notes 409, 439-41 and accompanying text (defining and describing inadequacies of using 100-year floodplain as a benchmark).

170. Singer, supra note 1 , at 336. The NFIP was originally located in the Department of Housing and Urban Development, but it migrated to FEMA when that agency was created in 1979. Wright, supra note 127, at 68. Both the NFIP, a "bureaucratic nomad," and FEMA were subsequently rolled into the Department of Homeland Security's Emergency Response and Preparedness Directorate. Scales, supra note 3, at 13.

171. Singer, supra note 1 , at 23.

172. 44 C.F.R. $\$ 64.5$ (2006). Subsidies exist where "expected losses arising out of a given group of risks, plus expenses relating to those risks, exceed the premium volume generated by the policies written." Singer, supra note 1 , at 327.

173. Scales, supra note 3, at 16 (citing Rawle O. King, Federal Flood Insurance: The Repetitive Loss Problems CRS-15 (2005), available at http://www.fas.org/sgp/crs/ misc/RL32972.pdf).

174. Steven E. Ehlmann, Conflict at the Confluence: The Struggle Over Federal Flood Plain Management, 74 N.D. L. Rev. 61, 65-66 (1998).

175. Flood Disaster Protection Act of 1973, Pub. L. No. 93-234, 87 Stat. 975 (1973). 
Congress attempted to strengthen the NFIP again in 1988. To reduce vulnerability to damages from future disasters and to boost post-disaster mitigation measures, Congress passed the Disaster Relief and Emergency Assistance Amendments of 1988. ${ }^{176}$ The Amendments take an important new approach of strategic retreat from dangerous locations, authorizing funding to acquire destroyed or damaged properties in flood hazard areas, to rebuild in non-hazardous areas, and to reduce exposure to flood risk through reconstruction standards. ${ }^{177}$ The Amendments also allow the President to deploy federal troops to assist in evacuation efforts, to distribute aid, and to perform necessary duties (other than law enforcement) in response to natural disasters. ${ }^{178}$

Predictably, it was not long before the nation's attention returned to the Mississippi River basin when the flood of 1993-the largest inland flood since the advent of the NFIP — put the federal insurance program and floodplain management policy to the test. ${ }^{179}$ Both failed miserably.

\section{ACT TWO: THE FLOOD OF 1993}

[The Mississippi River] cannot be tamed, curbed or confined[;] . . . you cannot bar its path with an obstruction which it will not tear down, dance over and laugh at. The Mississippi River will always have its own way, no engineering skill can persuade it to do otherwise

... .

-Mark Twain 180

\section{A. THE FLOOD}

In the spring and summer of 1993, record-breaking rains occurred in the Mississippi River basin, along with record-breaking river crests. ${ }^{181}$

176. Disaster Relief and Emergency Assistance Amendments of 1988, Pub. L. No. 100-707, 102 Stat. 4689 (codified at 42 U.S.C.A. \$ 5121-5202 (West 2002)) (1988). The 1988 amendments incorporated the Robert T. Stafford Disaster Relief and Emergency Assistance Act of 1974, Pub. L. No. 93-288, 88 Stat. 143 (1974).

177. 42 U.S.C.A. $\$ 5171$ (West 2002).

178. 42 U.S.C.A. $\$ 5170$ a. Once an area is declared a disaster, federal emergency responses are largely exempt from the analytical and procedural requirements of the National Environmental Policy Act, 42 U.S.C.A. § 4321(c). See Stafford Act, 42 U.S.C.A. $\S 5159$; Homeland Security Act, 6 U.S.C.A. $§ 313$. Other commentators have made cogent arguments for requiring FEMA to engage in more extensive analysis of its disaster relief programs. See, e.g., Katherine Hausrath, Tough Love: Should We Analyze Federal Emergency Management Agency Disaster Planning Under The National Environmental Policy Act?, 13 Hastings W.-Nw. J. Envtl. L. \& Pol'y 161 (2007); Michael Davis, Ethan Strell \& Judith Wallace, Environmental Protection After a Disaster: A Right or a Privilege?, NAT. ResourCes \& ENv'T, Spring 2006, at 15, 16.

179. Platt, supra note 6, at 26.

180. Mark Twain, Life on the Mississippi (1883); see also NOAA News Online, Quiet Beginning Heralded Nation's Worst Flood in 1993, Apr. 2, 2003, http://www.noaanews. noaa.gov/stories/s1125.htm.

181. Mo. State Emergency Mgmt. Agency, 10-Year Anniversary of the '93-94 FLOODS (2004), http://sema.dps.mo.gov/flood\%20anniversary.pdf [hereinafter 10-YEAR Anniversary of the '93-94 Floods]; Lee W. Larson, The Great USA Flood of 19934 (1996), http://www.nwrfc.noaa.gov/floods/papers/oh_2/great.htm. 
Precipitation stations recorded a year's worth of rainfall in only three months. ${ }^{182}$ In some counties, twenty inches fell in one month-“an extraordinary hydro-meteorological event."183 By August, the upper basin of the Mississippi and its tributaries, including the Missouri River, flooded 17,000 square miles in nine states. ${ }^{184}$ According to the National Weather Service, the 1993 flood broke records for both intensity and duration throughout Missouri, Minnesota, Iowa, and Illinois. ${ }^{185}$

Forty of 226 federal levees and 1,043 of 1,345 non-federal levees were over-topped or breached. ${ }^{186}$ In Missouri, floodwaters lapped over the steps of the St. Louis Arch. Widespread evacuations in the St. Louis area, including the St. Louis correctional facility, were compelled. ${ }^{187}$ Numerous highways and railroad routes in both Missouri and Kansas were closed. ${ }^{188}$ Meanwhile, the St. Joseph water treatment plant flooded and caskets in the Hardin Cemetery in Ray County surfaced. ${ }^{189}$ In Des Moines, Iowa, flood waters knocked out the city's treatment plant, leaving 250,000 residents without water supplies for drinking or sanitation for nearly a month. ${ }^{190}$ The failure of essential infrastructure throughout the Midwest and the release of hazardous substances from inundated Superfund sites and from hundreds of discarded barrels and propane tanks spread the effects of the flood far and wide. ${ }^{191}$

Moments before the floodwaters reached their doorsteps, a few local governments and floodplain residents discovered a way to game the NFIP system. Chesterfield, Missouri, located on the Missouri River just above its confluence with the Mississippi River at St. Louis, provides an example:

In the 1980s, an old agricultural levee was upgraded to a "100-year" level of protection, thus allowing the land behind it to be developed for industry with no floodplain management or mandatory purchase of flood insurance. As the 1993 flood crest rolled down the Missouri River toward St. Louis, owners of corporations behind the levee in Chesterfield rushed to buy flood insurance just in time to beat the five-day waiting period required before being eligible for insurance benefits. When the levee collapsed, 67 claims were filed in the area behind it, totaling $\$ 13.2$ million . . . 192

182. John Pitlick, A Regional Perspective of the Hydrology of the 1993 Mississippi River Basin Floods, Annals Ass'n Am. Geographers, Mar. 1997, at 149.

183. Id. at 135. See also 10-Year Anniversary of the '93-94 Floods, supra note 181.

184. Walter W. Hays, U.S. Geological Soc'y Natural Hazards Programs: Lessons Learned for Reducing Risk, http://water.usgs.gov/wid/html/HRDS.html (last visited Sept. 19, 2007).

185. LARSON, supra note 181.

186. Id.

187. 10-YeAr AnNiversary of the '93-94 Floods, supra note 181.

188. Id.

189. Id.

190. Wilkerson, supra note 13.

191. Platt, supra note 6, at 26.

192. Id. 
Chesterfield residents received a financial windfall in the form of federal insurance payouts. Meanwhile, however, 15,000 Missourians were left homeless. ${ }^{193}$ In all, fifty deaths were attributed to the flood, 100,000 people were displaced from their homes, and 100,000 buildings were destroyed or severely damaged. ${ }^{194}$ Nearly half a million acres of agricultural land along the rivers were inundated. ${ }^{195}$ About one-fourth of the cropland was covered with sand or scoured out, causing unprecedented crop losses. ${ }^{196}$ Over 500 counties were declared federal disaster areas. ${ }^{197}$ Estimates of total flood damages ranged as high as $\$ 20$ billion, with the federal government's costs exceeding $\$ 6$ billion. ${ }^{198}$

Chesterfield notwithstanding, the vast majority of affected Midwesterners did not have flood insurance before the 1993 disaster. Flood victims "were, on average, older, poorer, and more likely to live in a mobile home. Many homes in the flooded areas had market values of less than $\$ 25,000$, and often as low as $\$ 5,000$." 199 Due to poverty and federal enforcement failures, only ten percent of damaged structures were covered by the NFIP. 200

\section{B. The Aftermath: Floodplain Building Boom}

After the 1993 flood, the combination of direct subsidies and levee reconstruction stimulated an unprecedented amount of development in the Mississippi River floodplain. ${ }^{201}$ More than any other affected state, Missouri experienced a building frenzy. The State Soil Conservation Service assisted private owners in repairing agricultural levees, while the Department of Economic Development approved levee projects totaling over $\$ 2$ million for five counties. ${ }^{202}$ Meanwhile, the Corps of Engineers repaired federal levees along the Missouri and Mississippi Rivers and built a new levee solely to protect the town of Ste. Genevieve, population 4,500. ${ }^{203}$

In Missouri alone, approximately " 28,000 homes have been built and more than 6,000 acres of commercial and industrial space [have been] developed on land that was underwater in 1993."204 Building continues

193. 10-YeAr AnNiversary of THE '93-94 Floods, supra note 181.

194. Galloway, supra note 2, at 5; Beth Davidson, Note, How Quickly We Forget: The National Flood Insurance Program and Floodplain Development in Missouri, 19 WASH. U. J.L. \& POL'y 365, 365 (2005).

195. 10-YeAR AnNiversary of the '93-94 Floods, supra note 181.

196. Id.

197. Susan Saulny, Development Rises on St. Louis Area Flood Plains, N.Y. Times, May 15, 2007, at A13.

198. Galloway, supra note 2, at 5.

199. Platt, supra note 6, at 26.

200. 10-Year Anniversary of the '93-94 Floods, supra note 181; Tibbetts, supra note 16 , at 12 .

201. See Saulny, supra note 197.

202. 10-YeAr AnNiversary of THE '93-94 Floods, supra note 181.

203. Id.; Dirk Johnson, The Midwest Flooding: Flood Menaces Early French Settlement, N.Y. Times, July 11, 1993, at 1.

204. Saulny, supra note 197 . The new floodplain development is worth around $\$ 2.2$ billion. $I d$. 
on floodplains across Missouri, but the St. Louis area in particular is booming. ${ }^{205}$ Emboldened by the false sense of security provided by the new and repaired levees, people continue to be drawn to the area.

State and local governments have subsidized some of the development through tax incentives and other enticements. Once again, Chesterfield provides one of the most notorious examples:

THF Realty Inc. used Missouri's . . . tax increment financing . . . to build what is said to be the largest strip mall in the country on land in the Chesterfield Valley area of St. Louis County that was submerged in the floods of 1993 . The shopping center, which cost \$275 million to build, opened in 1999 and now has more than two million square feet of retail space .... The company was able to use the special financing because Missouri allows it for projects in areas that are considered blighted, or where development is not likely to occur without help ....206

In Chesterfield and other urban areas, "[f]aith in the levees seems to trump other concerns ...."207

\section{The Lessons: The Perverse Incentives of Federally Subsidized Flood Insurance}

The 1993 flood revealed that the federal government's emphasis on flood insurance and local floodplain management rather than floodplain abandonment had the perverse effect of stimulating the development of vulnerable areas and exacerbating the damages caused by flooding. ${ }^{208}$ In response, Congress amended the NFIP program and authorized buy-outs for some structures and cropland in the floodplain. Congress also created a special inter-agency commission to study existing flood control programs and to make recommendations for change. Although these efforts were necessary, in the end, they were mere baby steps that fell short of accomplishing necessary reforms.

\section{Reforming the National Flood Insurance Program}

In 1994, Congress adopted several amendments to the NFIP to minimize opportunities to game the NFIP system and to increase NFIP enrollment by strengthening statutory enforcement tools. First, the amendments attempted to counteract the Chesterfield phenomenon by increasing the waiting period from five to thirty days before newly purchased insurance could take effect. ${ }^{209}$ Second, Congress attempted to close loopholes that had allowed low NFIP enrollment in the area affected by the 1993 flood. Although the NFIP directed federally insured

205. Nicholas Pinter, One Step Forward, Two Steps Back on U.S. Floodplains, Sci., Apr. 8, 2005, at 207, 208.

206. Saulny, supra note 197.

207. $I d$.

208. Id

209. 42 U.S.C.A. § 4013(c)(1) (West 2000). 
lenders to require flood insurance for mortgages in the floodplain, property owners that had purchased policies when they first obtained their mortgages dropped them when it came time for renewal the next year. ${ }^{210}$ The 1994 amendments ratcheted up the pressure on lenders to ensure that homebuyers maintain insurance coverage, ${ }^{211}$ and extended the insurance requirement to all federally regulated banks, not just federally insured banks. ${ }^{212}$ An additional major reason for the NFIP's low market penetration in the affected area-the low average income of the flood victims and the low property values in the flooded areas-was not addressed in any meaningful way. ${ }^{213}$

A decade later, only modest improvements were evident. Missouri reported that, as of 2003 , there were 570 communities within the state participating in the NFIP, but nearly ninety communities within flood hazard areas did not participate in the program, making their residents ineligible for federal flood insurance. ${ }^{214}$ Nationwide, nearly half of all residences in the floodplain are still uninsured. ${ }^{215}$

\section{Strategic Retreat From Floodplains}

After the 1993 flood, some communities-supported by new federal legislation-began to experiment with retreating from flood-prone areas, rather than engineering yet more structural flood controls or tinkering with the NFIP requirements. Their efforts were stimulated by the Hazard Mitigation and Relocation Assistance Act of 1993, ${ }^{216}$ which expanded the Stafford Amendments of 1988 and made $\$ 130$ million available to Midwestern communities for disaster relief and hazard mitigation. ${ }^{217}$ Recipients were allowed to use funds to elevate buildings, improve drainage, or build flood-walls- " anything that can protect a community from flooding." 218 Buy-outs became the most popular option, taking nearly ninety percent of the available funds. ${ }^{219}$ Although previous buy-out programs

210. Scales, supra note 3, at 19 (citing Howard Kunreuther, Has the Time Come for Comprehensive Natural Disaster Insurance?, in ON RISK AND DisASTER: Lessons From Hurricane Katrina 179 (Ronald J. Daniels, Donald F. Kettl \& Howard C. Kunreuther eds., 2006)).

211. Galloway, supra note 2 , at 7.

212. 42 U.S.C.A. $\$ 4012 \mathrm{a}(\mathrm{b})(1)$; Scales, supra note 3, at 18 (citing U.S. GEN. ACCOUNTing Office, GAO-03-606T, Flood Insurance: Challenges Facing the National Flood Insurance Program 10 (2003), available at http://www.gao.gov/cgi-bin/getrpt? GAO-03-606T).

213. Platt, supra note 6 , at 26.

214. See 10-Year Anniversary of the '93-94 Floods, supra note 181 ("As of April 2003, there are 22,097 flood insurance policies in place in Missouri for a total coverage of $\$ 2,392,522,800 . ”)$.

215. Scales, supra note 3 , at $14-15$.

216. Pub. L. No. 103-181, 107 Stat. 2054 (1993) (amending 42 U.S.C.A. § 5170c).

217. Tibbetts, supra note 16 , at 11 . Previously, only $\$ 6$ million was available for relocation expenditures nationwide. Id.

218. Id. (quoting Larry Zensinger, chief of FEMA's Midwest mitigation program).

219. Id. See Platt, supra note 6, at 26 ("An important element of the Federal Emergency Management Agency's (FEMA) response to this flood . . . has been to buy up properties that are chronically flood-prone."). 
applied only in cases where property was repeatedly flooded or where damage exceeded half the market value, the 1993 hazard mitigation program allowed any building in the 100-year floodplain to be bought out.220 Over 200 local governments vied for federal funds to buy out buildings in flood-prone areas. ${ }^{221}$ As a result, more than 10,000 buildings were removed. ${ }^{222}$ Homeowners received pre-flood value for their homes plus federal loans to find new housing outside flood-prone areas. ${ }^{223}$ Federal funds were also provided for the acquisition of over two million acres of marginal farmlands. ${ }^{224}$ Throughout the Midwest, many of these properties have been converted to open space, wetlands, and forests. For instance, the Missouri Department of Conservation, the U.S. Fish and Wildlife Agency, and the Corps of Engineers acquired tens of thousands of agricultural acres in the floodplains, converting much of it to wetlands. 225 Minnesota is perhaps best known for its approach to taking flood-prone agricultural land out of production through programs that give considerable weight to the restoration of wetlands and other buffer ecosystems that serve to control and store flood waters. ${ }^{226}$ Minnesota has spent millions of dollars on conservation easements in flood-prone agricultural areas. ${ }^{227}$

Several urban communities have taken steps to limit floodplain construction as well, but have stopped short of removing existing structures. For example, Calhoun County, Illinois-located about forty miles northeast of St. Louis ${ }^{228}$ - made extensive post-flood revisions to its zoning code. The revised code prohibits all new residential construction in the 100-year floodplain and requires that damaged residences be elevated before they may be replaced. ${ }^{229}$ It also limits new commercial development to river-oriented industries, such as marinas, resorts, and ferry landings, and requires developers of river-oriented businesses to ensure adequate flood-proofing, either by elevating the structures or building a

220. Tibbetts, supra note 16, at 11-12. In Missouri, the State Emergency Management Agency and Department of Economic Development worked with seventy communities to move residents out of the floodplains. Nearly 4,500 parcels of land were acquired. 10-YEAR ANNIVERSARY OF THE '93-94 FloOds, supra note 181.

221. Tibbetts, supra note 16 , at 11 .

222. Id. Missouri's Community Buyout Program, for example, dedicated more than $\$ 30$ million of federal money to the acquisition of residential properties. Mo. STATE EmERgency Mgmt. Agency, Mo. Hazard Analysis, Annex B: Riverine Flooding, II B.V (2006), available at http://sema.dps.mo.gov/HazardAnalysis/AnnexB.pdf.

223. Press Release, Nat'l Wildlife Fed'n, NWF Plays Key Role in Program to Move Buildings Out of Flood Plains (Feb.-Mar. 1997), http://www.nwf.org/nationalwildlife/ article.cfm? issue ID $=53 \&$ articleID=659\#key.

224. Galloway, supra note 2 , at 7.

225. 10-YeAR ANNIVERSARY OF THE '93-94, supra note 181.

226. Jan Sendzimir, Steven Light \& Karolina Szymanowska, Adaptive UnderSTANDING AND MANAGEMENT FOR FloOdS 15 (1999), http://www.adaptivemanagement.net/Flooding.doc; Tibbetts, supra note 16, at 13 .

227. Tibbetts, supra note 16 , at 13 .

228. Id. at 8-9. The county was one of the hardest-hit areas during the flood. In 1993, floodwaters inundated roads, ferry landings, and bridge access, causing the county to be completely cut off to all but boat traffic for over three months. Id. at 8 .

229. Id. at 9 . 
500-year private flood levee. ${ }^{230}$

Many communities, however, failed to learn the lesson of the 1993 flood that some floodplains are best left in their natural condition. The construction boom in and around St. Louis is by no means an isolated example. ${ }^{231}$ Even the congressionally-charged, blue-ribbon panel studying the 1993 flood failed to call for aggressive change. Although the Interagency Floodplain Management Review Commission, headed by former Army Brigadier General Gerald Galloway, recommended a more balanced approach to floodplain management through both structural and nonstructural measures, it ultimately downplayed the role of wetlands in capturing and controlling releases of water from major floods:

Upland wetlands restoration can be effective for smaller floods but diminishes in value as storage capacity is exceeded in larger floods such as the Flood of 1993. Present evaluations of the effect that wetland restoration would have on peak flows for large floods on main rivers and tributaries are inconclusive. ${ }^{232}$

The Commission-through its Galloway Report-noted more of the floodplain should be reserved for wetlands, forests, and agriculture, but failed to recommend a major role for wetlands in providing flood protection. $^{233}$

\section{ACT THREE: THE HURRICANES OF 2005}

\section{A. The Hurricanes}

The final flood story of this Article takes place near the downstream reaches of the Mississippi River, some 2,300 miles from its source. ${ }^{234}$ In particular, this story occurs along the Gulf coasts of Louisiana, Mississippi, and Alabama - an area that is well acquainted with hurricanes. Louisiana alone suffered from some twenty hurricanes during the late twentieth century. ${ }^{235}$ The years 2004 and 2005 witnessed an extraordinary season of twenty-seven named storms, including fifteen hurricanes. ${ }^{236}$ Three of those hurricanes-Wilma, Rita, and Katrina-were, respectively, the first, fourth, and sixth strongest hurricanes of record in

230. Id. at $9-10$.

231. See supra Part III.B.

232. Gerald Galloway et al., Interagency Floodplain Mgmt. Review Comm., Sharing the Challenge: Floodplain Management into the 21st Century 47 (1994), http://edc.usgs.gov/sast/2P-00526.pdf [hereinafter The Galloway RePORT].

233. Id. at v-vi.

234. See 1 U.S. Geological Survey, supra note 12, at 351 (listing river's length as 3,705 kilometers).

235. David Roth, Louisiana Hurricane History: Late 20th Century, http://www. srh.noaa.gov/lch/research/lalate20hur.php (last visited Sept. 6, 2007) (describing Hurricanes Flossy (1956), Audrey (1957), Ethel (1960), Carla (1961), Hilda (1964), Betsy (1965), Camille (1969), Edith (1971), Carmen (1974), Babe (1977), Bob (1979), Danny (1985), Elena (1985), Juan (1985), Bonnie (1986), Florence (1988), Andrew (1992), Opal (1995), Josephine (1996), and Danny (1997)).

236. NOAA Satellite and Information Service, Climate of 2005 Atlantic Hurricane Season, http://www.ncdc.noaa.gov/oa/climate/research/2005/hurricanes05.html (last visited Sept. 15, 2007). 
the Atlantic Basin. ${ }^{237}$ Despite its lesser stature among that trio, Hurricane Katrina was the deadliest and most destructive. ${ }^{238}$ The storm unleashed winds and flooding that killed at least 1,300 people (with at least 2,000 people still missing), ${ }^{239}$ destroyed approximately 300,000 homes, ${ }^{240}$ and caused damage to property approaching $\$ 100$ billion. $^{241}$ Triggering a storm surge of up to twenty-seven feet in height from Mobile, Alabama, to New Orleans, Louisiana, Hurricane Katrina roared across a 93,000 square mile area with winds of up to 130 miles per hour. ${ }^{242}$

In New Orleans and along the Gulf Coast, a convergence of natural and human forces set the stage for the predictable-and indeed, predicted $^{243}$ - catastrophe. To fully understand the 2005 flood story, one must look backward to 1965, when Hurricane Betsy made landfall near Grand Island, Louisiana with 150 mile per hour winds, hurling northward through New Orleans, and finally diminishing near Little Rock, Arkansas. $^{244}$ Damages exceeded $\$ 1$ billion. ${ }^{245}$ In Betsy's wake, Congress authorized the Lake Pontchartrain and Vicinity Hurricane Protection Project, a massive system of levees intended to protect New Orleans. ${ }^{246}$ Additional flood control infrastructure followed. ${ }^{247}$ By 2005,

New Orleans rest[ed] within a bowl formed by 16 [foot] . . tall levees, locks, floodgates, and seawalls, the edge of the bowl extending for hundreds of miles. It [was] bisected from west to east by the Mississippi River, which [was] also contained within massive engineered embankments. Water [flowed] through and all around the city while its residents [went] about their daily routines. ${ }^{248}$

237. NOAA Noteworthy Records of the 2005 Atlantic Hurricane Season, http://www. noaanews.noaa.gov/stories2005/s2540b.htm (last visited Sept. 23, 2007).

238. Id.

239. Frances Fragos Townsend, Assistant to the President for Homeland Sec. and Counterterrorism, The Federal Response to Hurricane Katrina: LesSONS LEARNED 8 (2006), http://purl.access.gpo.gov/GPO/LPS67263.

240. Id. at 7 (counting homes that were completely destroyed or made uninhabitable).

241. Id. (describing Hurricane Katrina as "America's first disaster-natural or manmade-to approach the $\$ 100$ billion mark"). The Coastal Protection and Restoration Authority of Louisiana has compiled slightly different statistics, finding that as a result of Hurricanes Katrina and Rita, "[a]pproximately 200 square miles of marsh were destroyed, over 200,000 homes were damaged, over 1,400 Louisianans died, and more than one million state residents were displaced ...." CoAstal Prot. \& Restoration Auth. of La., Integrated Ecosystem Restoration and Hurricane Protection: Louisiana's Comprehensive Master Plan for a Sustainable CoAst (2007), http://acpra.org/assets/docs/epafinalreport5-2-07 [hereinafter LouisianA's CoMPREHENSIVE MASTER Plan].

242. Townsend, supra note 239, at 1 (comparing size of impacted area to the entire country of Great Britain).

243. See infra notes 256, 422-23, and accompanying text.

244. Greg Brouwer, The Creeping Storm, Civ. EnG'G, June 2003, at 46, 46.

245. Roth, supra note 235 (reporting $\$ 1.4$ billion in damages in southeast Louisiana and eighty-one deaths, including fifty-eight in Louisiana).

246. Donald T. Hornstein et Al., Ctr. for Progressive Reform, Broken Levees: Why They Failed 3 (2005) (citing Hearings on Hurricane Protection Plan for Lake Pontchartrain and Vicinity Before the Subcomm. on Water Resources of the H. Comm. on Public Works and Transportation, 95th Cong. (1978)).

247. Id. at 4-6.

248. Brouwer, supra note 244 , at 46. 
The levees provided security-later proved to be false-for settlement within the floodplain. Just as the Mississippi River floods in the midwestern states led to a flurry of rebuilding within the floodplain in the 1950s and $1990 \mathrm{~s},{ }^{249}$ so too did the Hurricane Betsy-inspired levees encourage floodplain development. ${ }^{250}$

The engineered infrastructure designed to protect New Orleans, as well as other human actions, triggered several unintended consequences. First, levees and dams constrict the Mississippi River, preventing the transportation of valuable sediments for the nourishment of wetlands and plains at the river's delta. As a result, "land loss on the delta plains has accelerated at an alarming rate." 251 Second, the dredging and maintenance of ship channels causes "[a]bnormally high rates of land loss." 252 Beyond the excavation of the channels themselves, the "[b]ow waves of large ships and wakes of smaller vessels alternately raise and lower water levels generating local waves and currents that erode the banks and enlarge the navigation channels." 253 Third, engineered structures, including groins, breakwaters, seawalls, and revetments, interfere with natural sand migration and dune restoration and alter sediment-replenishing currents, leading to coastland beach erosion. ${ }^{254}$ Fourth, the dredging of navigation channels, canals, and pipeline benches for oil and gas production causes a rapid conversion of land and wetlands to open water as sediment and water flow patterns are redirected. ${ }^{255}$

A full three years before Hurricanes Katrina and Rita, the New Orleans Times Picayune published an eerily prescient five-part series, Washing Away, that recognized many of these potential adverse consequences:

249. See supra Part III.B.

250. John McQuaid \& Mark Schleifstein, Exposure's Cost: Insurance Companies are Pulling Out, New Orleans Times-Picayune, June 25, 2002, at A1 ("But today cities and towns sprawl over wider areas. More businesses and more infrastructure are in place. East Jefferson, a semirural area when a hurricane flooded it in September 1947, is now a densely populated suburb."). In 2002, a spokesman for the State Farm Insurance Company noted the growing cost of storm damage, in part triggered by expanding land use patterns:

In 1965, [Hurricane] Betsy cost $\$ 5$ million to State Farm. . . . Projections looking at the same storm say it would cost us $\$ 1$ billion today because there has been a huge proliferation of building on the same land, and the value of Id. the land and what's on it has increased dramatically.

251. Robert A. Morton, USGS Open File Report 03-337, An Overview of Coastal Land Loss: With Emphasis on the Southeastern United States, If 63 ("River Modification") available at http://pubs.usgs.gov/of/2003/of03-337/landloss.pdf.

252. Id. II 57 ("Transportation").

253. Id.

254. Id. If 59("Coastal Construction").

255. Id. II 79 ("Wetland Losses"):

[Louisiana wetlands] form the surface of very thick and young sediments that are weak and compressible because of their deltaic origin. Today organic production in the Louisiana wetlands is incapable of keeping up with submergence because the influx of inorganic sediments has been eliminated primarily by human activities. On a geological time scale, sediment deposited by the Mississippi River compensated for the relative rise in sea level and Id. new land was constructed because of abundant sediment supply. 
Today [2002], billions of dollars worth of levees, sea walls, pumping systems and satellite hurricane tracking provide a comforting safety margin that has saved thousands of lives. But modern technology and engineering mask an alarming fact: . . . south Louisiana has been growing more vulnerable to hurricanes, not less. Sinking land and chronic coastal erosion-in part the unintended byproducts of floodprotection efforts-have opened dangerous new avenues for even relatively weak hurricanes and tropical storms to assault areas well inland. ${ }^{256}$

The article concluded with the observation of a levee manager in South Lafourche, Louisiana: "There's no doubt about it . . . [the] biggest factor in hurricane risk is land loss. The Gulf of Mexico is, in effect, probably 20 miles closer to us than it was in 1965 when Hurricane Betsy hit."257

Returning to 2005, the inadequacy of New Orleans's levee system became obvious during hurricane Katrina and its aftermath. Events unfolded during an agonizing six-hour period. ${ }^{258}$ In the pre-dawn hours before Katrina made landfall as a Category 3 storm on August 29, $2005,{ }^{259}$ flood waters in the Industrial Canal began to leak into surrounding neighborhoods. ${ }^{260}$ By dawn, portions of the Lake Borgne levee began to crumble. ${ }^{261}$ At 6:10 a.m., Katrina hit land on the west bank of the Mississippi River in Plaquemines Parish, triggering high winds and a twenty-one-foot storm surge that rose above nearby levees. ${ }^{262}$ By 6:30 a.m., two engineered waterways designed to convey floodwaters away from the city instead formed a "funnel" that constricted and energized a storm surge moving toward the city. ${ }^{263}$ The levees began to give way, flooding residential areas of eastern New Orleans. ${ }^{264}$ By 6:50 a.m., the funneled surge was pouring over floodwalls and levees into the Upper and Lower 9th Wards, Upper St. Bernard Parish, Gentilly, Bywater, Treme, and Broadmoor. ${ }^{265}$ By 7:45 a.m., catastrophic breaches developed in levees along the Industrial Canal, "send[ing] a wall of water into the Lower 9th Ward, killing people as houses [were] flattened and automobiles [were] tossed around like toys in a bathtub."266 By 10:30 a.m.,

256. John McQuaid \& Mark Schleifstein, In Harm's Way: Surging Water is the Biggest Threat to New Orleans, New Orleans Times-Picayune, June 23, 2002, at J2 (part 1 of 5). 257. Id. (quoting Windell Curole, general manager of the South Lafourche Levee District).

258. See Bob Marshall, City's Fate Sealed in Hours: Timeline Maps Course of Post-Katrina Deluge, New Orleans Times-Picayune, May 14, 2006, at 1.

259. Townsend, supra note 239, at 33.

260. Marshall, supra note 258.

261. Id.

262. Id.

263. David M. Driesen et al., Ctr. for Progressive Reform, An Unnatural Disaster: The Aftermath of Hurricane Katrina 13-14 (2005), http://www.progressivereform.org/articles/unnatural_Disaster_512.pdf (describing storm surges moving up the Mississippi River-Gulf Outlet ("MR-GO") and the Gulf Intracoastal Waterway). See also Marshall, supra note 258.

264. Marshall, supra note 258.

265. Id.

266. Id. 
catastrophic failures occurred on the east and west sides of the London Avenue Canal and at the 17th Street floodwall and levee. ${ }^{267}$ Overall, the levee system breached in up to thirty places, unleashing floodwaters that continued to rise for several days. ${ }^{268}$

In the wake of Katrina, at least eighty percent of New Orleans was submerged beneath up to twenty feet of water. ${ }^{269}$ The flooding was not caused directly by the relatively modest Category 3 hurricane. Rather, the flooding occurred as the city's 350-mile levee system-the legacy of Hurricane Betsy-failed, both through "over topping" as water levels rose above the height of the levees, and through "breaching" as breaks developed in the floodwalls and in some cases pushed them right over. ${ }^{270}$

In the New Orleans metropolitan area-home to over one million people, including some 100,000 low-income residents without automobiles $^{271}$-many residents were left stranded as floodwaters rose. Extensive media coverage indelibly etched heartbreaking images into the collective national consciousness-including families stranded on rooftops waving flags and flashing signs to attract the attention of helicopter rescuers, and forlorn pets separated from their families. ${ }^{272}$ Even after rescue, many did not fare well. The New Orleans Superdome, designated as the city's shelter of last resort for some 26,000 evacuees, lost portions of its roof the morning Katrina landed and spawned unverified reports of assaults, rape, and suicide within the shelter. ${ }^{273}$ Governmental rescue attempts proved to be inept, and in contrast to the 1927 flood, ${ }^{274}$ private aid was severely limited, as the Red Cross had decided a decade earlier that all of southern Louisiana was too dangerous for its operation of emergency shelters. ${ }^{275}$ Overall, only ten percent of Gulf Coast residents held federal flood insurance at the time of the 2005 hurricane season. ${ }^{276}$

The face of Katrina's stranded victims was disproportionately black. The nation's continuing racial divide became abundantly clear, evocative of the early nineteenth-century conscription of slaves to build flood-con-

267. $I d$.

268. Id.

269. Id.

270. Id.

271. See John McQuaid \& Mark Schleifstein, Left Behind, New Orleans Times-PicaYUNE, June 24, 2002, at 1 (predicting difficulty of evacuating area in advance of a hurricane or storm).

272. See Air Force Reserve Command, Combat Search and Rescue: Hurricane Katrina, http://www.afrc.af.mil/photos/ (last visited Sept. 7, 2007).

273. Nola.com, The Katrina Files: Timeline, http://www.nola.com/katrina/timeline/ (last visited Sept. 11, 2007) (noting that "[h]ellish scenes [were] reported from those stranded in the Superdome ... though later most [were] dismissed").

274. See supra note 84 and accompanying text (describing Red Cross response to the 1927 flood).

275. McQuaid \& Schleifstein, Left Behind, supra note 271 (On account of a shelter being flooded in South Carolina in the 1990s, the agency "bars shelters in areas that can be inundated by a storm surge from a Category 4 hurricane-which is all of south Louisiana").

276. See Scales, supra note 3 , at 15. 
trol levees, ${ }^{277}$ and the denial of evacuation services to black workers and refugees following the Mississippi flood of $1927 .{ }^{278}$ Charges of overt racism were also leveled against officials in the face of painfully slow and inadequate rescue efforts. Before a special congressional committee investigating the federal government's response efforts, victims and advocates provided emotional testimony through statements such as, "If it was not poor African-Americans who would be most affected by this, there would have been a [rescue] plan in place" and "[the victims] died from abject neglect . . . . We left body bags behind."279

\section{B. The Aftermath: The Absence of Leadership}

The aftermath of the 2005 hurricanes is rich with human pathos and drama. Three points are particularly relevant to this Article: First, the storms had important political consequences. Second, despite the painful lessons of the 1927 and 1993 floods that artificial flood control structures may actually lure people into harm's way, ${ }^{280}$ the immediate impulse after the storms was to build bigger levees. Third, the hurricanes prompted the state legislature of Louisiana to fill the leadership vacuum, at least in part, by creation of the Coastal Protection and Restoration Authority.

Contrary to the Mississippi River flood of 1927, which helped make a president by propelling then-Secretary of Commerce Herbert Hoover into the White House following his masterful rescue organization, ${ }^{281}$ the 2005 hurricanes contributed to the unmaking of a president, a governor, and nearly a mayor. The storms had a negative impact upon President Bush's approval ratings, with his rankings hitting new record lows in the wake of what many perceived as a bungled federal disaster response. ${ }^{282}$ Likewise, the inadequate response of Michael D. Brown, then director of the Federal Emergency Management Agency, fell under heavy criticism. ${ }^{283}$ The President's praise of the director's relief coordination was relentlessly caricatured during the period that led to the director's replacement. ${ }^{284}$ The post-storm criticism was bipartisan, also targeting

277. See supra note 48 and accompanying text.

278. See supra note 78 and accompanying text.

279. Black Witnesses Testify Racism Influenced Katrina Response, FoxNews.com, Dec. 6, 2005, http://www.foxnews.com/printer_friendly_story/0,2933,177900,00.html (reporting charges that "state, local and federal reaction was insufficient, in part because of racial bias" and noting that "[a]t times, black survivors who testified likened themselves to victims of genocide and the Holocaust, a comparison that didn't sit well with some lawmakers").

280. See supra Parts II.B, III.B.

281. See supra note 98 and accompanying text.

282. See Michael A. Fletcher \& Richard Morin, Bush's Approval Rating Drops to New Low in Wake of Storm, WASH. Post, Sept. 13, 2005, at A8 (reporting the results of a Washington Post-ABC News poll finding that fifty-four percent disapproved of the President's response to Hurricane Katrina, and that his overall approval ratings dropped from fortyfive percent to forty-two percent in the two weeks following the hurricane).

283. Spencer S. Hsu \& Susan B. Glasser, FEMA Director Brown Singled Out by Response Critics, Wash. Post, Sept. 6, 2005, at A1.

284. Id. (quoting President Bush's statement on September 2, 2005, "Brownie, you're doing a heck of a job"). See also Peter Baker, FEMA Director Replaced as Head of Relief 
Louisiana's democratic Governor Kathleen Blanco ${ }^{285}$ and New Orleans's democratic Mayor Ray Nagin. ${ }^{286}$ Despite criticism, however, the mayor won reelection some nine months after the hurricanes, albeit narrowly. ${ }^{287}$

A second relevant aspect of the hurricanes' aftermath was the initial desire to rebuild the very levees that had failed, and to resettle some of the same areas that had proved to be vulnerable to flooding. Just weeks after the storms, President Bush pledged, "This is our vision for the future, in this city and beyond: We'll not just rebuild, we'll build higher and better."288 Likewise, many in the Gulf coast region called for a flood control system built to endure a Category 5 storm. ${ }^{289}$ Still others simply could not believe that the failed levee system was to blame for much of the destruction. 290 Clinging to the conventional wisdom that flood control structures are the solution, and not part of the problem, some attempted to assign blame to an environmental group that had temporarily enjoined the Army Corps of Engineers from constructing a portion of the levee system before adequate study had been completed. ${ }^{291}$ Referring to the aborted Lake Ponchartrain Hurricane Protection Project, the retired chief counsel for the Army Corps of Engineers asserted, "If we had built

Effort, WAsh. Post, Sept. 10, 2005, at A1 (reporting that the Bush administration removed Brown on September 9, 2005 from his position as overseer of hurricane relief effort).

285. Survey USA, Approval Ratings for All 50 Governors, http://www.surveyusa.com/ 50State2005/50StateGovernorApproval0905SortedbyApproval.htm (last visited July 14, 2007) (listing Governor Blanco's approval rating on September 5, 2005 at forty-one percent, the ninth lowest in the nation). The Governor's approval rating fell from fifty percent on August 15, 2005, to forty-one percent on September 19, 2005, to thirty-three percent on Dec. 12, 2005. Id. (follow hyperlink titled "Louisiana Governor Approval Tracker").

286. Profile: Ray Nagin, BBC News, May 21, 2006, http://news.bbc.co.uk/2/hi/americas/ 4623922.stm (noting criticism of mayor "for delaying ordering a mandatory evacuation, ... for failing to mobilise an effective evacuation procedure," and for a "series of controversial remarks since the tragedy").

287. Id. ("Mr. Nagin was re-elected [in May 2006] having narrowly beaten challenger Mitch Landrieu, the lieutenant governor of Louisiana, in a second round run-off.").

288. Press Release, The White House, President Discusses Hurricane Relief in Address to the Nation, Sept. 15, 2005, http://www.whitehouse.gov/news/releases/2005/09/200509158.html (quoting statement of President George W. Bush).

289. John Schwartz, Category 5: Levees Are Piece of a $\$ 32$ Billion Pie, N.Y. Times, Nov. 29, 2005, at A1. But see Joel K. Bourne, New Orleans' Rebuilt Levees "Riddled With Flaws”, NAt'L Geographic News, May 6, 2007, http://news.nationalgeographic.com/ news/pf/26516454.html (explaining that "a storm even weaker than Katrina could breach the levees").

290. See infra Part IV.C.

291. Ralph Vartabedian \& Peter Pae, Katrina's Aftermath: A Barrier That Could Have Been, L.A. Times, Sept. 9, 2005, at A1. The criticism focused on the lawsuit Save Our Wetlands, Inc. v. Rush, which enjoined construction of a hurricane barrier around New Orleans pending completion of an adequate environmental impact statement. See also Save Our Wetlands, Inc. v. Rush, 424 F. Supp. 354 (E.D. La. 1976) (denying motion to dismiss challenge to final environmental impact statement for the Lake Ponchartrain Hurricane Protection Project). Cf. John Berlau, Greens vs. Levees: Destructive River-Management Philosophy, NAT'L Rev. Online, Sept. 8, 2005, http://www.nationalreview.com/ comment/berlau200509080824.asp (asserting that environmentalists "argued that the "natural' way would lead to better river management, but it was clear they had other agendas in mind besides flood control" and that they "were concerned because levees were allegedly threatening their beloved exotic animals and plants"). 
the barriers, New Orleans would not be flooded."292 Other groups countered the charges, explaining that it is "erroneous to suggest that the barrier project was derailed by the lawsuit. It could easily have progressed as soon as the appropriate Environmental Impact Studies were completed and the alternatives considered." 293 Moreover, even if the barrier had been constructed as initially planned, there is considerable doubt that the design specifications would have been adequate. ${ }^{294}$ In any case, within less than one year of Katrina, the administration backed off from its commitment to rebuild New Orleans' levees, as cost estimates tripled to $\$ 10$ billion. ${ }^{295}$ The nation waited anxiously during the 2006 hurricane season, hoping that the hastily rebuilt New Orleans levees would be adequate. ${ }^{296}$ The season proved to be a mild one, but the nervous watchfulness will undoubtedly be repeated for many years to come.

The creation of the Louisiana Coastal Protection and Restoration Authority was a third important post-hurricane development. ${ }^{297}$ Among other things, the Authority was charged with responsibility for coordinating a state vision for addressing the threat of hurricanes in the future. ${ }^{298}$ As the Authority explains, "For the first time in Louisiana's history, this single state authority will integrate coastal restoration and hurricane protection by marshalling the expertise [of various state agencies] to speak with one clear voice for the future of Louisiana's coast."299 After more than eighteen months of study, the Authority submitted for legislative approval in 2007 a master plan-Integrated Ecosystem Restoration and Hurricane Protection: Louisiana's Comprehensive Master Plan for a Sustainable Coast ("Master Plan") 300 _that it intends to guide "all coastal

292. Vartabedian \& Pae, supra note 291 (quoting Joseph Towers, retired chief counsel for the Army Corps of Engineers New Orleans District).

293. Press Release, Center for Progressive Reform, CPR's McGarity Raps Ex-Corps of Engineers Officials' Effort to Blame Environmentalists for Katrina Damage (Sept. 9, 2005), http://www.progressivereform.org/articles/Katrina-NR.pdf (noting that project was enjoined, in part, for failure to consider an alternative incorporating higher levees). See also DRIESEN ET AL., supra note 263, at 15.

294. DRIESEN ET AL., supra note 263, at 15.

295. Peter Whoriskey \& Spencer S. Hsu, Levee Repair Costs Triple to Almost $\$ 10$ Billion, Administration Says, WAsh. Post, Mar. 31, 2006, at A1 (citing administration's rebuilding coordinator for proposition that rebuilt levees might satisfy requirements of the national flood insurance program, and that after such reconstruction, "If a hurricane such as Katrina hit the area, there would not be catastrophic flooding," although there might be some "manageable" flooding).

296. Id. But see Bourne, supra note 289 (discussing engineers' finding of multiple flaws in levee system declared by Army Corps of Engineers to be restored to pre-Katrina strength).

297. See La. Rev. Stat. Ann. § 49:231.1 (2006). See also Coastal Protection and Restoration Authority of Louisiana, About Us, http://lacpra.org/intex.cfm?md=pagebuilder\& tmp $=$ home \&nid $=4 \&$ pnid $=0 \&$ pid $=2 \&$ fmid $=0 \&$ catid $=08$ elid $=0$ (last visited Oct. 20, 2007).

298. Coastal Protection and Restoration Authority of Louisiana, supra note 297.

299. Id. The legislation defines "coastal restoration" broadly, including attention to coastal wetlands, barrier shorelines or reefs, and the state coastal zone and "contiguous areas that are subject to storm or tidal surge." Id.

300. Id. The Master Plan's recommendations fall into three parts: (1) restoring sustainability to the Mississippi River delta; (2) restoring sustainability to the Atchafalaya River delta and Chenier plain; and (3) hurricane protection. Id. 
restoration and hurricane protection efforts in Louisiana over the next several decades." 301

The plan's suggestions are an interesting combination of the frustratingly timid and the breathtakingly bold. Clinging in part to heavily-engineered approaches, the plan calls for construction of yet more levees or flood control structures for various high-risk areas, ${ }^{302}$ despite acknowledging the concern that "levees built across swamp and marsh would stop the flow of water, leading to further wetland loss and creating impoundments that flood communities." 303 Although the plan recommends that some of the new structures be built to exceed the 100-year flood standard that proved inadequate during Hurricanes Katrina and Rita, ${ }^{304}$ it settles for only the 100-year standard for others. ${ }^{305}$ In addition, the plan envisions that the "level of protection provided will be proportional to the assets at risk." 306 Although such an asset-related standard may make economic sense, it threatens to perpetuate the neglect of impoverished populations, again shifting the risk of hurricane damage to the poor. ${ }^{307}$ As some critics have noted, the proposal is analogous to reducing protection for the elderly once they pass their prime income-earning years. ${ }^{308}$

Other aspects of the Master Plan are creative and more aggressive in scope. For example, the plan recognizes the critical role of natural flood control, citing to an "urgent need" to protect and restore coastal wetlands. ${ }^{309}$ To accomplish this restoration, the plan suggests innovative operation of existing flood control structures to provide water and sediment to nutrient-starved marshes. ${ }^{310}$ Boldest of all, the plan suggests the immediate closure of the Mississippi River Gulf Outlet, ${ }^{311}$ a channel that conducted floodwaters directly into the city of New Orleans during the

301. Coastal Protection and Restoration Authority of Louisiana, http://lacpra.org (last visited Oct. 20, 2007).

302. Louisiana's Comprehensive Master Plan, supra note 241 (suggesting the construction of new levees in areas including the north shore of Lake Pontchartrain, Barataria Basin and West Bank, Plaquemines Parish, Terrebonne Parish and Atchafalaya Delta, the Louisiana 1 Highway corridor, Acadiana, and the Chenier plain).

303. Id. (concluding that "[t]hese concerns must be addressed as projects are developed").

304. Id. (suggesting that some new levees "should raise protection over the level needed to withstand a storm that has a $1 \%$ chance of occurring in any given year").

305. Id. (suggesting 100-year-flood standard for the Lafourche Parish, central Barataria Basin, Oakville to Myrtle Grove, Caernarvon to White Ditch, LaRose to Golden Meadow, and New Iberia to Berwick/Patterson).

306. Id.

307. See supra notes 78, 199-200, 271-79, and accompanying text.

308. Ass'n of State FloodPlain Managers, Levees: The Double-edged Sword (2007), http://www.floodplain.org/pdf/Levee_Policy_Challenges_4-17-07.pdf [hereinafter Levees: The Double-edged Sword].

309. Louisiana's Comprehensive Master Plan, supra note 238.

310. Id. For example, the plan recommends "using existing navigation channels, such as the Gulf Intracoastal Waterway and the Houma Navigation Canal, as "new distributaries' that could channel water to more remote areas of the coast." Id. (described under heading Restoring Sustainability to the Mississippi River Delta).

311. Id. 
2005 storms, rather than away from the city. ${ }^{312}$ Reversing the historical trend, the plan calls for prioritizing flood control efforts over navigation enhancement in some cases." 313

\section{The Lessons: The Inadequacy of Engineered Flood Control, Again}

Hurricanes Katrina and Rita were natural events, but the loss of lives and property were acts of man. More specifically, acts of government.

-Oliver Houck ${ }^{314}$

\section{Unnatural Disasters}

Hurricanes Katrina and Rita reinforced the central lesson of the 1927 disaster: when flood control structures fail, they greatly exacerbate the damage caused by natural storms. Following the 1927 flood, federal officials had determined that the Army Corps of Engineers' approach to flood control had been a "monumental blunder,"315 causing a disaster that was "man-made" rather than natural. ${ }^{316}$ Almost eight decades later, analysis of the 2005 hurricanes yielded a similar conclusion: much of the damage was of human, rather than divine, origin. ${ }^{317}$ As the Wall Street Journal noted wryly, "God is getting a bum rap."318

Ultimately, the responsibility for a large portion of the devastation was assigned to the Army Corps of Engineers and its failed levees. An interagency task force estimated that if the levee system had not breached, fifty percent of direct losses might have been avoided. ${ }^{319}$ Similarly, a

312. See supra note 263 and accompanying text. See also infra note 323 and accompanying text.

313. Louisiana's Comprehensive Master Plan, supra note 241 (concluding that "appropriate economic mitigation plans will be needed after the channel is closed" to compensate for reduction in navigation).

314. Oliver A. Houck, Environmental Protection and Sustainable Development, in REport to Mayor Nagin's Bring New Orleans Back Commission 30, 30 (2005), http:// www.fromthelaketotheriver.org/files/final_report_11.29.pdf ("Federal hurricane protection monies were diverted to other projects; federal levees were improperly built and failed; [and] federal canals such as the Mississippi Gulf Outlet . . . brought the hurricane surges directly into St. Bernard, the Lower Ninth Ward, Lack Pontchartrain and the city proper.").

315. See supra note 91 and accompanying text.

316. See supra note 122 and accompanying text.

317. Sharon Begley, Man-Made Mistakes Increase Devastation of "Natural” Disasters, Wall St. J. Online, Sept. 2, 2005, http://online.wsj.com/public/article_print/SB1125611288 47329529.html (summarizing argument of Professor Theodore Steinberg, Case Western Reserve University, and asserting "While storms such as Hurricane Katrina are sometimes called an act of God or a natural disaster, the devastation they leave behind is not. Some scientists believe even the storms themselves could be at least partly man-made.").

318. Id.

319. 1 U.S. Army Corps of Eng'rs, Performance Evaluation of the New Orleans and Southeast Louisiana Hurricane Protection Sys.: Final Report of the Interagency Performance Evaluation TAsk Force I-4 (2006) [hereinafter PerFORMANCE EvAluATION]. The report was produced by the Interagency Performance Evaluation Task Force (IPET), established by the Chief of the U.S. Army Corps of Engineers, which was "comprised of some of the nation's leading engineers and scientists from gov- 
White House report asserted, "[The] flooding transformed Hurricane Katrina into a "catastrophe within a catastrophe." The task force concluded that the "[s]ystem did not perform as a system." 320 Instead, the network of federal and local structures was a haphazard "system in name only,"321 where floodwalls and levees of varying heights used mismatched materials that did not properly interface.322 Beyond failing to control floodwaters, the engineered structures actually concentrated the fury of the hurricanes, channeling it directly toward densely-settled areas. ${ }^{323}$ Moreover, the very presence of federal levees served as a magnet for settlement in vulnerable areas. ${ }^{324}$ As the floods of 1927 and 1993 vividly illustrated, reliance upon the false security of engineered flood control inevitably leads to tragic consequences. ${ }^{325}$

The Corps itself admitted culpability for the devastation of New Orleans in its response to a congressional request for an accounting. ${ }^{326}$ The Corps conceded that its structural defenses failed not because Congress had authorized only moderate Category 3 protection, which in turn let the floodwaters overtop the city's levees, but because levees and floodwalls simply collapsed. ${ }^{327}$ The Corps' construction engineers failed to account for the gradual sinking of native soils, leaving levees vulnerable to being pushed over by floodwaters. ${ }^{328}$ The Corps also failed to ensure that necessary repairs on levees and floodgates were completed or that pumps would continue functioning during a catastrophic storm event. ${ }^{329}$

\section{The Value of Healthy Wetlands}

In the wake of the hurricanes, officials gained an increased appreciation of the ability of healthy wetlands to dissipate the force of storm

ernment ... , academia and private industry." Press Release, U.S. Army Corps of Eng'rs, News Release No. PA-05-16 Interagency Performance Evaluation Task Force-Repair Improvements for the New Orleans Hurricane Protection System (Dec. 9, 2005), http://www. hq.usace.army.mil/cepa/releases/interagency_Eval.htm.

320. 1 Performance Evaluation, supra note 319, at I-3 (noting that [i]ncomplete sections of the system," along with "subsidence and construction below the design intent due to error in interpretation of datums" resulted in "lower protective elevations").

321. Id.

322. Ann Carrns, Holes in the Dike: Long Before Flood, New Orleans was Prime for Leaks, WAll ST. J., Nov. 25, 2005, at A1.

323. See supra note 312 and accompanying text.

324. Editorial, Katrina's Unlearned Lessons, WAsh. Post, June 7, 2006, at A22.

325. See supra Parts II.A, III.A.

326. Katrina's Unlearned Lessons, supra note 324, at A22. The nine-volume 6000-page report was delivered to Congress on July 10, 2006. Press Release, U.S. Army Corps of Eng'rs, Release No. PA-06-10, Army Forwards Preliminary Technical Report on Louisiana Coastal Protection and Restoration to Congress (July 10, 2006), http://www. hq.usace.army.mil/cepa/releases/lacpr.htm.

327. Katrina's Unlearned Lessons, supra note 324.

328. Id.; Press Release, Robert Sanders, UC Berkeley-Led Levee Investigation Team Releases Final Report at Public Meeting in New Orleans, May 20, 2006, http://www.berkeley.edu/news/media/releases/2006/05/24_leveereport.shtml (announcing R.B. SEED, ET AL., Independent Levee Investigation Team Final Report: Investigation of the Performance of the New Orleans Flood Protection System in Hurricane Katrina ON August 29, 2005 (2006), http://www.ce.berkeley.edu/ new_orleans/.

329. Carrns, supra note 322 , at A1. 
surges and to absorb flood waters. After the 1927 flood, society was unable to learn this lesson: the science of ecology would not develop for several more decades, and wetlands were still derisively labeled "swamps."330 Even in the wake of the 1993 flood, analysts were reluctant to acknowledge the value of wetlands. For example, although the 1994 Galloway Report recommended both structural and "nonstructural" flood control measures, it trivialized as "inconclusive" the evidence that wetland restoration could reduce peak flood flows. ${ }^{331}$ But by the 2005 storm season, the notion of "ecosystem services" had gained tractionincluding the qualitative and quantitative study of the societal benefits provided by healthy wetland ecosystems. ${ }^{332}$ Analysts of Hurricane Katrina and Rita were finally ready to focus on the flood-taming services performed by wetlands. As the director of civil works for the Army Corps of Engineers noted, the evolving science of hurricanes now recognizes that the "loss of coastal wetlands protecting New Orleans from storms, as well as the lowering of the ground level in the area [from leveeinduced subsidence], have reduced the city's natural safeguards from flooding." 333 Ironically, much of the wetland loss-and subsequent storm damage - can be attributed to dams and levees designed to prevent flooding. ${ }^{334}$ In addition, the loss was caused by the dredging of thousands of miles of canals to promote navigation and to facilitate operations of the petroleum industry. ${ }^{335}$ The National Academy of Sciences calculates that some nine thousand miles of pipeline traverses coastal Louisiana to support half a million oil and gas production facilities. ${ }^{336}$

Post-hurricane reports emphasized that Louisiana is currently composed of about 3.5 million acres of wetlands, an area roughly comparable in size to the state of Connecticut. 337 Approximately 1.2 million acres of

330. See, e.g., Nauman v. Big Tarkio Drainage Dist. No. 2, 87 S.W. 1195, 1195 (Mo. Ct. App. 1905) (approving the idea that "the reclamation of swamp and overflowed lands is highly beneficial" because it destroys "[d]isease breeding areas . . . resulting in the improvement of sanitary conditions, and waste places made tillable increasing production and public revenue").

331. See supra note 232 and accompanying text.

332. See James Salzman, Valuing Ecosystem Services, 24 Ecology L.Q. 887, 891 (1997) (noting that a study published in Nature estimated the aggregate value of ecosystem services world-wide at up to $\$ 54$ trillion per year) (citing R. Costanza et al., The Value of the World's Ecosystem Services and Natural Capital, 387 Nature 253 (1997)).

333. Whoriskey \& Hsu, supra note 295.

334. See, e.g., Jeffrey Zinn, Cong. Res. Serv. RS22276, Coastal Louisiana Ecosystem Restoration After Hurricanes Katrina and Rita, at CRS-2 (2006), available at $\mathrm{http} / / / \mathrm{www} . n a t i o n a a g l a w c e n t e r . o r g / a s s e t s / \mathrm{crs} / \mathrm{RS} 22276 . p d f$.

335. Louisiana Sea Grant, Louisiana Hurricane Recovery Resources: Barrier Islands and Wetlands, http://www.laseagrant.org/hurricane/archive/wetlands.html (noting that such dredging "has accelerated saltwater intrusion").

336. Nat'l Research Council, Comm. on the Restoration \& Prot. of Coastal La., Drawing Louisiana's New Map: Addressing Land Loss in Coastal louisiana 36 (2006), available at $\mathrm{http}: / / \mathrm{www} . n a p . e d u /$ books/0309100542/html/27.html.

337. ZINN, supra note 334, at CRS-2 (describing remaining wetlands as occupying "an area slightly large[r] than Connecticut"). The entire state of Louisiana is 43,561.85 square miles (27.8 million acres). U.S. Census Bureau, Louisiana Quick Facts, http:// quickfacts.census.gov/gfd/states/22000.html (last visited Sept. 11, 2007). 
Louisiana's coastal wetlands have been lost since the 1930s, ${ }^{338}$ and it continues to lose up to 16,000 wetland acres (twenty-five square miles) each year. ${ }^{339}$ The 2005 hurricanes destroyed over two hundred square miles of coastal wetlands during one month alone. ${ }^{340}$ Overall, the rate of land loss in coastal Louisiana exceeds that of any other place in the world. ${ }^{341}$ As a result, the area has been rendered increasingly susceptible to hurricanes and flooding. ${ }^{342}$ Although difficult to predict with precision, as a general rule of thumb, every two to four linear miles of coastal wetlands may reduce storm surge by a height of one foot. ${ }^{343}$ Moreover, research suggests that most of the flooding associated with Hurricanes Katrina and Rita could have been prevented if eighty miles of coastal marsh had been restored downstream of New Orleans. ${ }^{344}$

\section{INTERMEZZO: THE PHENOMENON OF "DOUBLE TAKES"}

Each of the Mississippi River stories considered in this Article is compelling in its own right. But an even more powerful narrative emerges when the stories are combined and integrated into the relevant historical, social, and legal contexts. The effort reveals a century of risk shifting, with a concomitant evasion of responsibility. At the governmental level, the responsibility for flood management has moved back and forth among local, state, and federal governments. Such government policies invariably determine which individuals will bear the risk of storm and flood damage. Ironically, governmental subsidies have repeatedly shifted risk away from the very actors who exacerbate the potential for catastrophic storm damage or otherwise engage in risky behavior. Moreover, the integrated narrative highlights the underappreciated phenomenon of double takes - the extent to which risk-prone development "takes" taxpayer dollars through at least two categories of subsidies: (1) federal subsidies (including the construction and maintenance of federal flood control structures, the provision of below-cost flood insurance, and the availability of federal disaster relief) and (2) Fifth Amendment compensation when regulation forbids building (or rebuilding) in flood and coastal zones. In essence, this creates a "damned if you do, damned if you don't" scenario: If communities allow risky development, then federal taxpayers inevitably foot the bill to protect that development through structures, insurance, and disaster relief. And if communities forbid risky development through land use regulations, then taxpayers may be forced to compensate disappointed developers. At times, the

338. ZINN, supra note 334, at CRS-2 (referring to wetlands "converted to open water").

339. Louisiana's Comprehensive Master Plan, supra note 241.

340. Id.

341. Coastal Protection and Restoration Authority of Louisiana, supra note 297.

342. See id.

343. Louisiana Sea Grant, supra note 335 (noting variations in accordance with storm intensity and coastal elevation).

344. America's Wetland Foundation, FAQ's, http://www.americaswetlandresources. com/background_facts/basicfacts/FAQs.html (last visited Sept. 4, 2007). 
subsidies are cumulative, where the same tract of land qualifies for more than one subsidy, or in the case of "repetitive loss" 345 where the same structure is built time and again with insurance proceeds awarded after loss through flooding.

\section{A. Taking One: A Century of Risk-Shifting Subsidies}

As recounted in the prologue of Part I, the mighty Mississippi River presented a challenge that no self-respecting engineer could resist. The nation's Army Corps of Engineers stepped in, engaging in a type of domestic war to control the river. In this era before the development of the ecological sciences and conservation biology, there was a widespread failure to appreciate the broad, interconnected nature of rivers and their floodplains, or oceans and their adjacent beach-dune-barrier island complexes. Rather, the compartmentalized thinking of the time was unable to recognize the relationship between flood control, navigation, and development; floods were viewed as isolated acts of God, without acceptance of the human responsibility for magnifying flood damage. ${ }^{346}$ As a result, society remained uneasy about the federal government's constitutional authority to control floods and was therefore content with the Army Corps of Engineers' constrained "levees only" role. This approach would prove to be disastrous, as taxpayer-funded levees strait-jacketed the river and shifted the risk of flooding to downstream communities.

The flood of 1927-the subject of Part II-brought international attention to the lower Mississippi by washing away entire cities and causing billions of dollars of economic damage. Society began to acknowledge that the disaster had been magnified greatly by the failure of levees, transforming natural flooding into a "manmade disaster." 347 But instead of rejecting engineered flood control, the nation ultimately called for an even more elaborate system of structures that would include floodways and retention areas expected to provide a safety valve for the overflow of levee-constricted rivers. The bulk of the responsibility of flood control was placed on the federal government, which in turn delegated responsibility to the Army Corps of Engineers. The Corps proceeded zealously, virtually unfettered by administrative limits that would not appear until the enactment of the Administrative Procedure Act of 1946. ${ }^{348}$ At the same time, federal flood control legislation made clear that the federal government retained broad immunity from liability for flood damage. ${ }^{349}$ Thus, floodplain communities shifted the risk of vulnerable development to federal taxpayers, supporting the construction of engineered structures that ultimately proved to do more harm than good in many instances. Even more directly, risk was shifted to black workers who were forced at

345. See infra notes 461-67 and accompanying text.

346. See supra note 93 and accompanying text.

347. See supra note 122 and accompanying text.

348. 5 U.S.C.A. $\$ \S 500-96$ (West 2007).

349. See infra notes 517, 519 and accompanying text. 
gunpoint to sandbag the river during the height of the flood and who were denied evacuation assistance. ${ }^{350}$

As a mid-century sequel to the flood of 1927 , flood waters claimed towns and fields in the Midwest in the 1940s and then again in the 1950s. ${ }^{351}$ Congress authorized yet more structural flood control and created two additional subsidies for floodplain development through the Disaster Relief Act of $1950^{352}$ and the National Flood Insurance Act of 1968. ${ }^{353}$ Although the insurance legislation recognized the need for landuse restrictions on new floodplain development, in many instances, local officials instead promoted industrial and residential expansion into floodplains. ${ }^{354}$ Either way, the risk was shifted to taxpayers to pay for structures and subsidized insurance to protect floodplain inhabitants. Moreover, although the Supreme Court had endorsed the constitutionality of local zoning in its 1920 decision Euclid v. Ambler, ${ }^{355}$ it had also raised the specter of constitutional limits in its 1922 decision Pennsylvania Coal, ${ }^{356}$ thus introducing a new mechanism for would-be floodplain developers to shift the risk of unwise land speculation to the taxpayers of communities that enacted protective land use controls.

Risk-shifting subsidies continued with renewed force following the 1993 flood, the subject of Part III. By late century, there was little local appetite for controlling floodplain and coastal development. This became apparent in the post-flood analysis, which revealed numerous loopholes in the federal flood insurance program that weakened compliance with the call for local land-use regulations. Moreover, the post-war building boom had morphed into the phenomenon of suburban sprawl. On top of all this, the "property rights" movement began in earnest about 1985,357 building upon the regulatory takings doctrine of Pennsylvania Coal. ${ }^{358}$ As a result, land-use regulators met with a powerful deterrent-a determined group of advocates that used the Fifth Amendment as a constitutional shield against government regulation. Consequently, floodplain construction (and reconstruction) continued largely unabated. In St. Louis, for example, the nation's largest strip mall sprouted up on the very site that had been catastrophically inundated by floodwaters in $1993 .{ }^{359}$

350. See supra note 78 and accompanying text.

351. See supra notes 120-21, 126, 130-45 and accompanying text.

352. See supra note 128 and accompanying text.

353. See supra note 163 and accompanying text.

354. See supra Part III.B.

355. Village of Euclid v. Ambler Realty Co., 272 U.S. 365, 389-96 (1926).

356. Pennsylvania Coal Co. v. Mahon, 260 U.S. 393, 414 (1922).

357. See Christine A. Klein, The New Nuisance: An Antidote to Wetland Loss, Sprawl, and Global Warming, 48 B.C. L. REv. (forthcoming 2007), available at http://ssm.com/ abstract $=967992$.

358. See Pennsylvania Coal Co., 260 U.S. at 414-15.

359. See supra note 206 and accompanying text. See also Scientists: California, St. Louis Risk Katrina-Level Floods, USA TodAy, Feb. 19, 2006, available at http://www.usatoday. com/tech/science/2006-02-19-flooding_x.htm?POE=click-refer (citing Jeffrey Mount, University of California, for proposition that "[u]rban sprawl has left some densely populated U.S. regions vulnerable to flooding on a similar scale to what the Gulf Coast suffered after Hurricane Katrina"). Other regions follow the same pattern. For example, construction 
Thus, developers continued to enjoy the benefits of sprawling into vacant land, while shifting the risk onto taxpayers for flood control structures, insurance, and disaster relief, and also discouraging local regulation with the threat of takings litigation.

Finally, the 2005 hurricanes illustrated many of the same lessons. But, they also introduced a new dimension to this risk-shifting history, pitting the infrastructure-intensive interests of the shipping industry and the wetland-destroying interests of the oil and gas industry against the interests of urban dwellers, many of them poor and black. ${ }^{360}$ Many of the hurricanes' victims might not have chosen willingly to live in the floodplain or to forego federal flood insurance, but might not have had any other realistic financial option. ${ }^{361}$ Thus, in this instance, the risk of failed structures was borne by a segment of the population less able to do so (at least in a financial sense) and less likely to have the means to evacuate in advance of the storms.

\section{B. Taking Two: Government Compensation for Halting Risky DeVelopment}

In the context of the regulatory takings doctrine, the United States Supreme Court has twice directly addressed the constitutionality of land-use regulations that limit development in floodplains and coastal zones. In both instances, the Court issued opinions adverse to government regulators. ${ }^{362}$

First, in 1987, just two years after the modern property rights movement got underway, ${ }^{363}$ the Court decided First English Evangelical Lu-

along the Florida coast continues frenetically, despite numerous hurricanes, including the Great Miami Hurricane of 1926, Hurricane Betsy of 1965 (striking Florida before moving on to New Orleans), and Hurricane Wilma of 2005. As one commentator explains, "[t]he temporary lull in hurricane activity in Florida, from 1969 to 1989, spurred a reckless building boom, ... . putting billions of dollars worth of condos and hotels within reach of storm surges." Begley, supra note 317 (citing Roger Pielke, Jr., University of Colorado, Boulder).

360. See Daniel A. Farber, Disaster Law and Inequality, 25 LAw \& InEQ. 297, 297-98 (2007) (assembling "evidence of the disproportionate impact of disasters based on race, gender, and age").

361. Id. at 302-03; Marc R. Poirier, Takings and Natural Hazards Policy: Public Choice on the Beachfront, 46 Rutgers L. Rev. 243, 260-62 (1993).

362. During roughly the same time period, the Court also struck two "exactions" required as conditions for approval of permits to expand buildings located near the coast and next to a floodplain. See, e.g., Dolan v. City of Tigard, 512 U.S. 374, 394-95 (1994) (finding unconstitutional exaction of title to floodplain property and bicycle path easement as condition for approval of permit to expand business); Nollan v. Cal. Coastal Comm'n, 483 U.S. 825, 839-42 (1987) (finding unconstitutional exaction of public easement across beachfront land as condition for approval of permit to expand beachfront home).For additional takings decisions of the Supreme Court relevant to the regulation of land use near aquatic areas, see Tahoe-Sierra Pres. Council, Inc. v. Tahoe Reg'l Planning Agency, 535 U.S. 302, 305 (2002), Palazzolo v. Rhode Island, 533 U.S. 606, 611 (2001), and Suitum v. Tahoe Reg'l Planning Agency, 520 U.S. 725, 728-31 (1997).

363. Most commentators trace the origin of the movement to the 1985 publication of Richard A. Epstein, Takings: Private Property and the Power of Eminent DoMAIN (1985). See generally Klein, supra note 357, at 5 n.16. 
theran Church of Glendale v. County of Los Angeles. ${ }^{364}$ In that case, the appellant church operated a retreat center and recreational area for handicapped children on its creek-side property. ${ }^{365}$ In 1978, a storm inundated the watershed with eleven inches of rain and destroyed all buildings on the church property. ${ }^{366}$ In response, the county enacted an interim ordinance that it determined was "required for the immediate preservation of the public health and safety." 367 The ordinance prohibited all construction and reconstruction within the flood zone, designated as an interim flood protection area. ${ }^{368}$ The church brought suit, alleging that the ordinance denied it "all use" of the property, seeking damages for an alleged regulatory taking rather than invalidation of the ordinance. ${ }^{369}$

The Court's decision approved the concept of "temporary takings," providing that "where the government's activities have already worked a taking of all use of property, no subsequent action by the government can relieve it of the duty to provide compensation for the period during which the taking was effective." 370 Despite the fact that the Court addressed only the question of remedy in situations where a taking has otherwise been demonstrated-assuming for the purposes of litigation that the challenged ordinance deprived the appellant of all use of its property ${ }^{371}$ - the case casts a cloud upon the future permissibility of government regulators to restrict floodplain development. As the majority acknowledged,

We limit our holding to the facts presented .... We realize that even our present holding will undoubtedly lessen to some extent the freedom and flexibility of land-use planners and governing bodies of municipal corporations when enacting land-use regulations. But such consequences necessarily flow from any decision upholding a claim of constitutional right. ${ }^{372}$

Justice Stevens's dissent did not dismiss the opinion's potential chilling effect in such benign terms: "The Court has reached out to address an issue not actually presented in this case, and has then answered that selfimposed question in a superficial and, I believe, dangerous way." 373 See-

364. First English Evangelical Lutheran Church of Glendale v. County of Los Angeles, 482 U.S. 304, 340-41 (1987).

365. Id. at 307.

366. Id.

367. $I d$.

368. Id.

369. Id. at 308-09.

370. Id. at $318,321$.

371. Id. at 321 ("We also point out that the allegation of the complaint which we treat as true for purposes of our decision was that the ordinance in question denied appellant all use of its property.") (emphasis added).

372. Id. (Rehnquist, C.J., joined by Brennan, White, Marshall, Powell, and Scalia, J.J.) (explaining, "of course [we] do not deal with the quite different questions that would arise in the case of normal delays in obtaining building permits, changes in zoning ordinances, variances, and the like").

373. Id. at 322 (Stevens, J., dissenting, joined in part by Blackmun and O'Connor, J.J.). The dissent explained, 
ing the potentially disastrous consequences of floodplain construction, the dissent found it "imperative to stress that the Court does not hold that appellant is entitled to compensation as a result of the flood protection regulation that the county enacted." 374 Suggesting that such construction constituted a common law nuisance that the county could forbid without compensation, ${ }^{375}$ the dissent forcefully asserted:

Thus, although the Court uses the allegations of this complaint as a springboard for its discussion of a discrete legal issue, it does not, and could not under our precedents, hold that the allegations sufficiently alleged a taking or that the county's effort to preserve life and property could ever constitute a taking. ${ }^{376}$

Of potential importance to future local planners seeking to enact ordinances in compliance with the National Flood Insurance Program, ${ }^{377}$ the dissent concluded, "As far as the United States Constitution is concerned, the claim that the ordinance was a taking of [the church's property] should be summarily rejected on its merits."378

Five years later, in Lucas $v$. South Carolina Coastal Council, the Court returned to the question of the constitutionality of uncompensated regulation of property subject to storms and flooding. ${ }^{379}$ This time, the dispute centered upon the Isle of Palms, a barrier island off the coast of South Carolina. ${ }^{380}$ The island was home to a posh resort, developed by David Lucas, the petitioner in the lawsuit that would follow:

In 1984, Lucas headed up a development partnership that purchased the Wild Dunes Beach and Racquet Club on the Isle of Palms for twenty-five million dollars. The partnership, Wild Dunes Associates, developed an exclusive 1500-acre gated community that included

\footnotetext{
The policy implications of today's decision are obvious and, I fear, far reaching. Cautious local officials and land-use planners may avoid taking any action that might later be challenged and thus give rise to a damages action. Much important regulation will never be enacted, even perhaps in the health and safety area. Were this result mandated by the Constitution, these serious implications would have to be ignored. But the loose cannon the Court fires today is not only unattached to the Constitution, but it also takes aim at a long line of precedents in the regulatory takings area. It would be the better part of valor simply to decide the case at hand instead of igniting the kind of litigation explosion that this decision will undoubtedly touch off.
}

Id. at 340-41. See also id. at 340 n.17 (explaining, "[a]s one commentator concluded: "The chaotic state of taking law makes it especially likely that availability of the damages remedy will induce land-use planning officials to stay well back of the invisible line that they dare not cross." ").

374. Id. at 325 .

375. Id. at 326-28 (asserting that a government that "may not be 'burdened with the condition that [it] must compensate such individual owners for pecuniary losses they may sustain, by reason of their not being permitted, by a noxious use of their property, to inflict injury upon the community"' (quoting Mugler v. Kansas, 123 U.S. 623, 668-69 (1887)).

376. Id. at 328 (emphasis added).

377. See supra notes $168-73$ and accompanying text.

378. First English Evangelical, 482 U.S. at 328.

379. Lucas v. S.C. Coastal Council, 505 U.S. 1003, 1006-07 (1992).

380. Id. at 1008. For a discussion of Lucas in the context of wetland protection, see Klein, supra note 357. 
2500 residences and vacation homes, two golf courses, and a large marina. The project made Lucas a wealthy man, generating $\$ 100$ million in sales its second year. In 1986, Lucas sold off his interest in the partnership. Just months later, he re-purchased for himself two of the last undeveloped beachfront lots for the sum of $\$ 975,000$. The fate of these two lots-severed from some 2500 other lots in the resort-would become the limited focus of the Supreme Court litigation. ${ }^{381}$

Despite its attractiveness for development, the island is "notoriously unstable," and for "roughly half of the .. . 40 years [preceding the lawsuit], all or part of [the Lucas] property was part of the beach or flooded twice daily." 382 To protect island development, state and local authorities took numerous measure, including sandbagging in the vicinity of threatened structures and completing a $\$ 1$ million beach renourishment project. ${ }^{383}$

In 1989, Hurricane Hugo struck the Isle of Palms and elsewhere along the South Carolina coast, killing thirty-five people and causing $\$ 6$ billion in damage. ${ }^{384}$ Specifically designed to avoid such damage, the South Carolina Beachfront Management Act established setbacks that prohibited construction within a specified distance of coastal dunes and other protected areas. ${ }^{385}$ The state law was enacted in compliance with the federal Coastal Zone Management Act ("CZMA"). ${ }^{386}$ As applied to the property of plaintiff/petitioner David Lucas, the statute precluded all development on his last two beachfront lots. ${ }^{387}$ Although petitioner conceded that "discouraging new construction in close proximity to the beach/dune area is necessary to prevent a great public harm," the Court found that the state law constituted a regulatory taking for which compensation must be provided. ${ }^{388}$ Moreover, the Court agreed with the lower court's findings that the subject oceanfront property was "valueless" in its natu-

381. Klein, supra note 357 , at 15 .

382. Lucas, 505 U.S. at 1038 (Blackmun, J., dissenting) (observing "Between 1957 and 1963, petitioner's property was under water. Between 1963 and 1973, the shoreline was 100 to 150 feet onto petitioner's property. In 1973, the first line of stable vegetation was about halfway through the property.").

383. As Justice Blackmun noted, "Between 1981 and 1983, the Isle of Palms issued 12 emergency orders for sandbagging to protect property in the Wild Dune development [and a state agency determined that habitable structures were in imminent danger of collapse]." Id. at 1038-39 See also Respondent's Brief on the Merits at *1, Lucas v. S.C. Coastal Council, 505 U.S. 1003 (1992) (No. 91-453), 1992 WL 672613 ("The erosion problems between 1981 and 1983 were so serious that the Mayor of the locality issued twelve emergency orders ... for sand scraping and sand bagging to protect man-made structures on lots in the immediate vicinity of petitioner's property."); Coastal Management in South Carolina Fact Sheet: Coastal Program Time Line, www.scdhec.net/environment/ocrm/pubs/docs/CCF/FS _time.pdf (last visited Oct. 21, 2007).

384. South Carolina State Climatology Office, Hurricanes, South Carolina Hurricane Climatology-Notable South Carolina Hurricanes, http://www.dnr.sc.gov/climate/sco/Tropics/hurricanes_affecting_sc.php (last visited Sept. 6, 2007).

385. Lucas, 505 U.S. at 1007-09 (discussing the South Carolina Beachfront Management Act, S.C. Code AnN. § 48-39-290(A)).

386. Coastal Zone Management Act of 1972, 16 U.S.C.A. $\S \S 1451-56$ (West 2006).

387. Lucas, 505 U.S. at 1007.

388. Id. at 1020, 1022. 
ral state. ${ }^{389}$ In so holding, the Court established a new categorical rule of "total takings" under which regulators must compensate landowners whenever regulation "deprives land of all economically beneficial use."390 The Court also recognized a nuisance-like defense to the rule for regulations that "inhere in ... the restrictions that background principles of the State's law of property and nuisance already place upon land ownership." 391

Lucas provides a clear illustration of the double takes phenomenon. In addition to the Fifth Amendment compensation that Mr. Lucas received for the inability to develop his two lots, he had previously benefited from numerous taxpayer subsidies that made the vulnerable barrier island amenable to development:

... . [B]oth Lucas's ability to build on the beach and the value of his beachfront lots were augmented by government action. Public authorities had constructed a bridge to provide access to the island, roads to drive on, water and sewage systems to serve the houses, and beach protection measures to prevent them from washing away. On top of that, the government has helped underwrite flood insurance to cushion the loss when those measures fail. All of these taxpayerfinanced improvements contributed to the value of Lucas's property and in all likelihood spelled the difference between its being attractive for development and a financially worthless strip of shifting sand. 392

Like First English, the decision in Lucas has the potential to shift the cost of risk prevention to taxpayers. The Lucas petitioner conceded the validity of the legislative findings that an undisturbed beach/dune zone "protects life and property by serving as a storm barrier which dissipates wave energy and contributes to shoreline stability in an economical and effective manner." 393 Nevertheless, the Court required state taxpayers to compensate Lucas for adhering to the regulation, ${ }^{394}$ creating the potential to chill the enchantment of state and local flood hazard regulations, as

389. Id. at 1027. But see id. at 1065 (Stevens, J., dissenting) (complaining that "the Court offers no basis for its assumption that the only uses of property cognizable under the Constitution are developmental uses") (emphasis in original).

390. Id. at 1026-29.

391. Id. at 1029 (explaining that regulations that deprive property of all economically beneficial use without compensation must "in other words, do no more than duplicate the result that could have been achieved in the courts-by adjacent landowners .... under the State's law of private nuisance, or by the State under its complementary power to abate nuisances that affect the public generally, or otherwise").

392. Daniel D. Barnhizer, Givings Recapture: Funding Public Acquisition of Private Property Interests on the Coasts, 27 HARv. EnvTl. L. REv. 295, 303-04 (2003) (quoting Edward Thompson, Jr., The Government Giveth, EvnTL. F., Mar.-Apr. 1994, at 22, 22 (emphasis omitted)) (asserting that Lucas received a windfall "to the extent that the state had to compensate him for enhanced property value that occurred through state action rather than Lucas's individual investments in that property, either active (such as building improvements on the land) or passive (such as waiting for market forces to drive up values)").

393. Lucas, 505 U.S. at 1021 n.10.

394. Id. at 1027. 
encouraged by the NFIP and it coastal counterpart, the CZMA. After Lucas, for example, the state ultimately acquiesced in the development of the property by reselling it to recoup the compensation paid to Lucas. ${ }^{395}$

\section{DENOUEMENT: A SECOND LOOK AT DOUBLE TAKES}

The nation can approach flooding in only a few ways: (1) ignore it, (2) keep the water away from the people, (3) pay the people who get wet, or (4) keep the people away from the water.

-Oliver Houck (1985) $)^{396}$

Despite the double-takes phenomenon that has evolved over the past century, signs of reform have begun to appear. Most recently, Hurricanes Katrina and Rita served as a forceful reminder of the foolhardiness of ignoring the potential for flooding, attempting to keep the water away from the people through artificial flood control, or "pay[ing] the people who get wet" with federally subsidized insurance and disaster relief. Moreover, there are also signs that the regulatory takings doctrine is in decline, thereby paving the way for responsible regulation of floodplain and coastal development.

This Part explores innovative alternatives to past practices, assembling a collection of hopeful signs and new opportunities. Specifically, we propose a transformative approach to three key areas: floodplain management; federal flood insurance; and regulatory takings. Viewed through the unifying lens of risk-shifting, this Part examines reforms that place the risk of unwise development back onto the risk-takers themselves.

\section{A. Restricting Federal Subsidies for Floodplain DeVElopment}

\section{Taming Floods Naturally}

The Mississippi River stories teach that it is sheer folly-and even hubris - to purport to control the river, to prevent it from flooding, and to ensure the safety of floodplain communities with engineered structures alone. At the same time, the stories show that it is wasteful and dangerous to squander the natural flood control mechanisms that nature has provided, including wetlands, sand dunes, and barrier islands. The value

395. Vicki Been, Lucas v. The Green Machine: Using the Takings Clause to Promote More Efficient Regulation?, in Property Stories 221, 239 (Gerald Korngold \& Andrew P. Morriss eds., 2004). Moreover, subsequent to argument in the Lucas case, but before the issuance of the opinion, South Carolina amended its statute to provide for the issuance of "special permits" that would allow the "construction and reconstruction of habitable structures seaward of the baseline." Lucas, 505 U.S. at 1010-11.

396. Houck, supra note 149, at 159. Professor Houck dismisses the first option as an approach that has failed "[a]s a matter of politics and humanity," and dismisses the second and third options in light of their expensive and "spectacularly unsuccessful" history. Id. He concludes that Congress is left with the fourth option, but notes that it continues to cast "more than [a] wistful eye on the never-ending dams and levees and politically attractive disaster relief grants of [options] (2) and (3)." Id. 
of natural flooding has been recognized throughout history. For over 5,000 years, the Egyptians co-existed with the Nile River and its seasonal floods, which brought life-giving water as well as nutrient-laden silt to the floodplain. ${ }^{397}$ Like the farmers in the Nile River Valley, generations of U.S. farmers factored floods and droughts into their costs of doing business. ${ }^{398}$ Bumper crops produced by the thick, black soil of the Mississippi River valley-perhaps the richest soil on earth-made it worth the gamble. ${ }^{399}$ But somehow that appreciation of flood-nourished soils was lost over time. In retrospect, the Supreme Court got it exactly wrong when it agreed that coastal dunes on a barrier island are "valueless" in their natural state, ${ }^{400}$ and that communities must pay landowners to keep them from building in floodplains. ${ }^{401}$ This sort of logic merely shifts the risk of flood-prone development away from those who benefit from it, thereby removing any incentive to avoid such risky behavior in the future.

Fortunately, there are signs that these lessons have begun to permeate the national consciousness. In 2002, Louisiana launched a massive public awareness initiative, America's Wetland: Campaign to Save Coastal Louisiana, designed to "rais[e] awareness of the impact of Louisiana's wetland loss and increase support for efforts to conserve and save coastal Louisiana." 402 The campaign asserts that "America's wetland is one of the largest and most productive expanses of coastal wetland in North America," but is disappearing at a rate of twenty-five to thirty-five square miles (16,000-22,400 acres) each year. ${ }^{403}$ The campaign cites numerous benefits provided by the wetlands, including protection of more than two million coastal residents from hurricanes and storm surges and buffering the primary port system of the nation. ${ }^{404}$ As a solution to continued wetland loss, the campaign points to the master plan for ecosystem restoration and hurricane protection prepared in the aftermath of the 2005 storm season. ${ }^{405}$ Although subject to a measure of criticism for its continued reliance on some engineered flood control, ${ }^{406}$ the plan is noteworthy for

397. Donald T. Hornstein, Environmental Sustainability and Environmental Justice at the International Level: Traces of Tension and Traces of Synergy, 9 DukE EnvTL. L. \& POL'y F. 291, 294 (1999).

398. Wilkerson, supra note 13 , at 41.

399. Id. For example, after the flood of 1952, farmers in the recently inundated floodplain "boasted some of the best [crop] yields they ever experienced," due to the rich, new alluvium soils that were deposited by the flood. Kollmorgen, supra note 136, at 212.

400. See supra notes 378-95 and accompanying text.

401. See supra notes 364-76 and accompanying text.

402. Gulfbase.org. America's Wetland, http://www.gulfbase.org/organization/view.php? old=america8217s (last visited Sept. 7, 2007); see also America's Wetland: Campaign to Save Coastal Louisiana, History, http://www.americaswetland.com/custompage.cfm?pageid =2\&eid=5 (last visited Sept. 5, 2007).

403. America's Wetland: Campaign to Save Coastal Louisiana, History, http://www. americaswetland.com/custompage.cfm?pageid\&eid=5 (last visited Oct. 20, 2007).

404. Id.

405. Louisiana's Comprehensive Master Plan, supra note 241. The master plan was approved by the state legislature on May 30, 2007. Coastal Protection and Restoration Authority of Louisiana, http://www.lacpra.org (last visited Oct. 20, 2007).

406. See supra Parts III.C.2, IV.C. 
its comprehensive integration of wetland restoration into its hurricane protection plan. ${ }^{407}$

The Association of State FloodPlain Managers has also laid the groundwork for important reforms by starkly acknowledging the danger created by the nation's thousands of miles of levees. ${ }^{408}$ The Association asserts that levees are inherently unreliable: "given enough time levees either will be overtopped or will fail-leading to severe flood impacts on an unsuspecting population." 409 In part, this is due to broad reliance upon the often inadequate design standard based upon the 100-year flood. ${ }^{410}$ The Association notes:

Ironically, . . . the nation and citizens would fare better if a community built a "99-year levee," because this would lead to the continuation of both mandatory flood insurance as well as continued floodplain management construction practices-which collectively would lower vulnerability and risk much more than would a 100-year levee by itself. ${ }^{411}$

Acknowledging that an alternative "500-year" design standard is just as arbitrary as the 100-year standard, the Association nonetheless suggests that this should be the basis for the minimum accepted level of protection. ${ }^{412}$ As a second basis for reform, the Association recognizes that levees provide a false sense of security, leaving thousands of people "living at great risk behind levees, thinking that they are perfectly safe because they do not believe that the government (federal, state, or local) would allow them to live behind the levee if such were not the case." 413 Third, the Association highlights a widespread failure of governments to inform their citizens of the risks of over-reliance on levees to reduce the impact of flooding, and of the residual risk of catastrophic failure that inevitably remains. ${ }^{414}$ Finally, the Association notes that communities relying upon levees shift the risk of flood damage to federal taxpayers, and

407. Louisiana's Comprehensive Master Plan, supra note 241 (asserting that the master plan "is the first document to completely incorporate hurricane protection projects with projects aimed at rebuilding Louisiana's rapidly eroding coastal wetlands").

408. Levees: The Double-edged Sword, supra note 308, at 1 (describing the organization as a "non-profit professional organization dedicated to the reduction of flood losses in the United States"). See also Ass'N of State FloodPlain Managers, Inc., National Flood Programs and Policies in Review (2007), http://www.floods.org/PDF/ASFPM_ NFPPR_2007.pdf [hereinafter National Flood Programs and Policies].

409. Levees: The Double-Edged Sword, supra note 308, at 1, 13 (emphasis added).

410. Id. at 3 .

411. Id. at 4.

412. Id. at 3-4 (asserting that "[a]lthough there is no perfect answer to this problem, adopting a 500-year standard would move the United States closer to what it currently demands in fire protection and ... . would mirror what other nations have done, many of which that have a considerably longer history of levee management").

413. Id at 5 (noting confusion between the insurance of buildings-relying upon the 100-year standard-and public safety).

414. The Association asserts,

Risk communication is the responsibility of all levels of government and the private entities associated with development, lending, insurance, and conducting any business in or near flood hazard areas near levees . . . . Due to poor communication, levees promote a false sense of security. Investors, 
fail to recognize and accept local responsibility for reducing flood risk. ${ }^{415}$ Based upon these observations, the Association recommends a drastic change of course. For new development, the Association argues that "levees are not a wise community choice and should never be used to protect undeveloped land so development can occur in the flood risk area behind the levee." 416 Existing levees, in turn, reflect "a time when the nation was convinced it could engineer its way out of flooding," and should be recognized "only as a method of last resort for providing a limited means of flood risk reduction for existing development." 417

Post-Katrina recommendations concerning the Atchafalaya River-a distributary that draws water away from the Mississippi River-provide yet a third compelling account of the growing openness toward reform. Over time, the Atchafalaya drew off more and more of the Mississippi's flow, threatening to capture the Mississippi and become its main route to the Gulf of Mexico. ${ }^{418}$ Such a major shift is a regular part of the Mississippi's history, occurring about every one thousand years. ${ }^{419}$ As naturalist/writer, John McPhee explained in 1989:

The Mississippi River, with its sand and silt, has created most of Louisiana, and it could not have done so by remaining in one channel ... . Southern Louisiana exists in its present form because the Mississippi River has jumped here and there within an arc about two hundred miles wide, like a pianist playing with one hand-frequently and radically changing course, surging over the left or the right bank to go off in utterly new directions. Always it is the river's purpose to get to the Gulf by the shortest and steepest gradient. ${ }^{420}$

But such a shift in course was anticipated to destroy the economies of Baton Rouge and New Orleans by harming the numerous industries that depended upon the fresh water and navigation channel provided by the Mississippi. ${ }^{421}$ Ironically, many predicted that New Orleans would be destroyed if the Mississippi River were allowed a natural safety valve outside its main channel, when it was the artificial constriction of the river

property owners, business owners, and others tend to live and conduct busiId. at 9 .

ness with little consideration of the levee systems that protect their property.

415. As the Association explains,

Communities realize that they can gain the benefits of a levee (an increased local tax base and minimal disturbance to the people and infrastructure of the community) while externalizing the costs of levee failure and overtopping to the federal taxpayers through disaster relief, federal levee construction and repair programs, and the perception that, when flooded, they are the victims. The result is a nation in which millions of citizens and hundreds of communities neither recognize their flood risk nor accept responsibility for Id. at 11 . reducing that risk.

416. Id. at 1 (emphasis added).

417. Id. (emphasis in original).

418. MCPhEE, supra note 50, at 4-5.

419. Id.

420. Id. at 5 .

421. Id. at 6. 
in its present channel that actually led to the 2005 post-hurricane floods. 422 Capturing the sentiment of the time, McPhee writes,

For the Mississippi to make such a change [to the Atchafalaya] was completely natural, but in the interval since the last shift Europeans had settled beside the river, a nation had developed, and the nation could not afford nature .... For nature to take its course was simply unthinkable. ${ }^{423}$

To prevent the river from changing course, the Army Corps of Engineers took a heavily-engineered approach, including construction of a dam and weir system about one hundred miles northwest of New Orleans. ${ }^{424}$ A few visionaries decried this attempt, including Tulane law professor Oliver Houck, who characterizes the effort to restrict the Mississippi River to only one course as "the third-greatest arrogance." 425

Arrogance or not, the Corps waged a structural battle against the river. ${ }^{426}$ Despite the Corps' Herculean efforts, the river maintained its threat to shift course. In the decade following the St. Louis flood of 1973, which posed a particular threat, the Washington Post opined, "Who will win as this slow-motion confrontation between humankind and nature goes on? No one really knows. But after watching Mt. St. Helens and listening to the guesses about its performance, if we had to bet, we would bet on the river." 427

In the wake of Hurricanes Katrina and Rita, surprisingly well-accepted proposals suggest loosening the Corps' historic stranglehold on the Atchafalaya River, a suggestion that would have been unthinkable until very recently. ${ }^{428}$ Plans include "letting the river loose" by allowing a signifi-

422. See supra Part IV.

423. McPheE, supra note 50, at 6.

424. Id. at 9, 10-11. As McPhee noted, Congress

decided that "the distribution of flow and sediment in the Mississippi and Atchafalaya Rivers is now in desirable proportions and should be so maintained." The Corps was thereby ordered to preserve [conditions as they existed in] 1950. In perpetuity, at [the distributary point], thirty per cent of the latitude flow was to pass to the Atchafalaya.

Id. at 11. See also Cornelia Dean, Time to Move the Mississippi, Experts Say, N.Y. TIMEs, Sept. 19, 2006, at F1 (discussing Corps' locks, dams, and power stations near Lettsworth, an area north of Baton Rouge and about 100 miles northwest of New Orleans).

425. McPheE, supra note 50, at 11.

426. Id. at 7. An Army Corps of Engineers documentary about the Mississippi River control structures asserted:

This nation has a large and powerful adversary. Our opponent could cause the United States to lose nearly all her seaborne commerce, to lose her standing as first among trading nations. ... We are fighting Mother $\mathrm{Na}$ ture. . . It's a battle we have to fight day by day, year by year; the health of Id. at 7 . our economy depends on victory.

427. Id. at 50 (quoting a November 1980 Washington Post editorial).

428. As one member of the Louisiana's Governor's Commission for Coastal Restoration observed,

One of the major obstacles to doing any of this [wetland restoration] pre-

Katrina was the navigation industry. . . . As a result of Katrina, everyone's thinking has become more flexible. Katrina brought all that home: how vulnerable this economic infrastructure has become. So there is a greater readi- 
cant portion of the water in the main Mississippi River channel-together with its wetland-nourishing sediment-to escape into alternative waterways, including the Atchafalaya River. ${ }^{429}$

\section{Insuring Wisely}

The NFIP, coupled with the federal refusal to engage in land-use management in the floodplain, allows developers to reclaim flood-prone areas that are otherwise financially uninhabitable. Not only do existing floodplain communities survive, they are often expanded and new ones regularly spring up because the financial risk of disaster has been foisted onto a larger pool of taxpayers. ${ }^{430}$ The problems are two-fold: the persistence of floodplain occupants, particularly developers, who encroach and remain in flood-prone areas, and the governmental failures at every level to stop floodplain development.

We propose an array of reforms aimed at these two fundamental problems. In doing so, we build on existing proposals pending in Congress, and we propose several additional steps.

A flurry of reform bills aimed at the first problem-improvident occupation of the floodplain-have been introduced since 2005. The overall thrust is to increase participation in the NFIP program and to reduce federal costs. Common elements include requiring FEMA to update its flood maps and to increase fines on lenders who fail to enforce mandatory insurance requirements for federally-backed mortgages. ${ }^{431}$ One of the latest, the Flood Insurance Reform and Modernization Act of 2007, would also phase out subsidies for vacation homes and nonresidential properties. ${ }^{432}$ The bill is similar to one that passed in the House in

ness today to think more boldly about how we can manage the river in a way that will help restore and build wetlands.

Dean, supra note 424 (quoting James T.B Tripp, attorney for Environmental Defense).

429. Peter Whoriskey, Louisiana Plan to Reclaim Land Would Divert the Mississippi,

Wash. Post, May 1, 2007, at A3.

430. Scales, supra note 3 , at 41 .

Congress recognizes a connection between providing insurance and supporting development. Congressional findings indicate that the availability of insurance often determines the practicability of development. Developers themselves declare the connection between feasibility of development in flood-prone areas and the NFIP. . . . [O]rganizations representing developers' rights implied that their ability to continue operating hinged on the presence of federal assistance. Despite the mandate to limit construction in flood-prone areas, there appears to be consensus that the NFIP supports, if not encourages, development on dangerous sites.

McMillan, supra note 166, at 499-500 (citations omitted).

431. Flood Insurance Reform and Modernization Act of 2007, H.R. 1682, 110th Cong. (2007). See Press Release, Congressman Richard Baker, Voting 416-4, House Overwhelmingly Supports Bipartisan Flood Insurance Reform Bill (June 27, 2006)), available at http:// baker.house.gov/html/release.cfm?id=208 (describing the Flood Insurance Reform and Modernization Act of 2006, H.R. 4973, 109th Cong. (2006)).

432. Flood Insurance Reform and Modernization Act of 2007, supra note 431. The proposed Flood Insurance Reform and Modernization Act of 2007 would require FEMA to update its flood maps, $i d$. $\S 21$, increase penalties for non-compliant lenders, $i d$. $\S 6$, and phase-out insurance subsidies for vacation and secondary homes, id. $\S 4$. It would also instruct the Comptroller General to report to Congress on the extension of mandatory 
2006 but died in the Senate. ${ }^{433}$ The banking industry opposes several of the provisions, and the odds of passage are currently uncertain. ${ }^{434}$

All three reforms - updating flood maps, increasing fines on non-compliant lenders, and phasing out subsidies for vacation homes and nonresidential properties-are essential. They are not, however, enough. Three additional steps must be taken.

First, flood insurance coverage must be expanded. Just as people who drive automobiles must maintain auto insurance, people that occupy floodplains should be required to maintain adequate flood insurance. ${ }^{435}$ At present, participation in the NFIP is appallingly low. There seems to be no solid consensus on the exact level of NFIP participation, but it is clear that only a small fraction of communities and residents situated in floodplains are enrolled. Official estimates range from sixteen percent to fifty percent participation for all homeowners subject to mandatory insurance requirements, although participation for mortgages originated after 1994 is higher. ${ }^{436}$ Participation also varies tremendously by region. Prior to 1993, only one in ten rural midwestern residents had NFIP insurance. ${ }^{437}$ Prior to 2005 , only one in ten Gulf Coast residents held flood insurance, due both to extreme poverty and to exemptions from NFIP requirements for residents residing behind the (failed) levee system. ${ }^{438}$ The levee system qualified as a "flood control device" under the NFIP, so at-risk homes behind the levees were not required to obtain flood insurance. ${ }^{439}$ Those homeowners could have purchased optional flood insur-

insurance requirements to properties located in flood-prone areas that would require insurance but for the existence of a levee or other structural protection device and on the extension of mandatory purchase requirements to non-federally related loans. Id. § 3(b).

433. Stacy Kaper, Flood Insurance Reform's Future Uncertain, Am. BANKer, Apr. 10, 2007, at 5 .

434. Christopher Drew \& Joseph B. Treaster, Politics Stalls Plan to Bolster Flood Coverage, N.Y. TimEs, May 15, 2006, at A1 (reporting that "lobbying pressures and regional rivalries" have stood in the way of meaningful reforms in previous years).

435. Forty-seven states plus the District of Columbia require drivers to maintain automobile insurance. Rachel Jenny, The Louisiana Legislature's Attempt to Reduce Auto Insurance Rates With No Pay, No Play: The Answer, A Step in the Right Direction, or Completely Useless?, 66 LA. L. Rev. 543, 543 (2006) (citing InsuranCe INFORMATION INstitute, The Insurance Fact Book 2005, at 50-53 (2005)).

436. Scales, supra note 3, at 14-15. As of 2006, 20,000 communities were participating in the NFIP program and approximately 5.2 million people carried NFIP insurance. See Press Release, Fed. Emergency Mgmt. Agency, Reduced Rates for Pacific N.W. Communities (Sept. 29, 2006), available at http://www.fema.gov/news/newsrelease.fema? id=30378; Press Release, Fed. Emergency Mgmt. Agency, Release No. HQ-05-280, National Flood Insurance Program Announces Simplified Adjustment Process for Policyholders Affected by Hurricane Katrina (Sept. 20, 2005), http://www.fema.gov/news/newsrelease.fema?id= 19018; U.S. Gen. Accounting Office, GAO-03-606T, Flood Insurance: Challenges Facing the Nat'L Flood Ins. Program 3 (2003), available at http://www.gao.gov/cgibin/getrpt?GAO-03-606T.

437. The Galloway Report, supra note 232, at 9, 131.

438. Scales, supra note 3 , at $14-15,20$. "This response, entirely foreseeable, led to disaster when the levee at the 17th Street Canal ruptured, inundating thousands of homes." Id. at 20 n.69.

439. 44 C.F.R. $§ 65.10$ (2007). See Federal Emergency Management Agency, Frequently Asked Questions, http://www.fema.gov/plan/prevent/fhm/fq_pol.shtm (last visited Sept. 15, 2007) ("What is required to certify a levee as providing protection from the base flood?"). 
ance at minimal rates, but the illusion of safety fostered by the leveesand, in some cases, the lack of means-compelled them to forego it. ${ }^{440}$ When floodplain occupants have little or no insurance, the federal treasury (and the taxpayers who fund it) pay the costs of their gamble in the form of after-the-fact disaster relief, including emergency supplies, housing, and federal grants and loans. Although at least one commentator has called for dismantling the NFIP altogether, ${ }^{441}$ we believe that finelytuned reforms aimed at increasing participation, but only for those activities that are appropriate to floodplain occupation, are a better bet.

Flood insurance should be required for all properties within the entire floodplain, not just those that carry mortgages and not just those lacking levees but situated within the 100-year floodplain. A "100-year flood" describes an event or an area subject to a one percent probability of a certain size flood occurring in any given year. The boundary of the 100year flood is commonly used in floodplain mitigation programs, including the NFIP, to identify areas of significant flood risk. However, the phrase is a misnomer. Even if a 100-year flood occurs in any given year, there is still a one percent chance of a similar occurrence in the following year, ${ }^{442}$ that is, a one percent annual probability of a major flood occurrence. ${ }^{443}$ Put another way, "[t]here is approximately a $26 \%$ chance that a 1 -in-100 flood will strike a home during the lifetime of a 30-year mortgage." 444 And even if a levee protects that home, odds are, the levee will eventually fail. This is a high-risk event that typically has catastrophic effects.

Congress should also transform the NFIP's "one size fits all” approach to premium rates to an approach that reflects the degree of risk in each area. $^{445}$ Even before Hurricane Katrina, homeowners in just three hurricane-prone states-Florida, Louisiana, and Texas-collected nearly half the money paid out by the NFIP program since 1978.446 Although most of the victims of the 2005 hurricanes had no insurance, claims from those who did could surpass $\$ 22$ billion, an amount that exceeds claims paid in all previous years of the program. 447 Once FEMA completes updating its floodplain maps to incorporate the best geological and hydrological data available, it will be relatively easy to identify areas with high, medium,

440. Scales, supra note 3, at 20 n.69. See Nat'l Research Council, Committee on a Levee Policy for the National Flood Insurance Program, Levee Policy for the National Flood Insurance Program (National Academy Press 1982) ("It is short-sighted and foolish to regard even the most reliable levee system as fail-safe.").

441. McMillan, supra note 166, at 505.

442. Primer on Natural Hazard Management, supra note 15, at A1.

443. Scales, supra note 3 , at 9 .

444. Id. at 18 .

445. Drew \& Treaster, supra note 434, at Al.

446. Id.

447. Insurance Claims Payment Process in the Gulf Coast After the 2005 Hurricanes: Hearing Before the Subcomm. on Oversight and Investigations of the Comm. on Financial Services, No. 110-7, 110th Cong. 159 (2007) (testimony of David I. Maurstad, Director and Federal Insurance Administrator, Mitigation Division, Federal Emergency Management Agency). 
and low risk and to set premium rates accordingly. ${ }^{448}$

As a second proposed reform, we believe that FEMA's enforcement capabilities must be strengthened significantly. While existing legislative proposals would bolster enforcement against inattentive lenders, ${ }^{449}$ no measures have been taken or proposed with respect to non-compliant communities and developers. ${ }^{450}$ Congress must enhance FEMA's ability to take action against both the communities that fail to enforce their floodplain ordinances and the floodplain occupants who benefit from the communities' haphazard oversight. ${ }^{451}$ Although FEMA is directed to monitor the implementation of appropriate ordinances, its only recourse against non-complying communities is to disqualify them from the NFIP program. ${ }^{452}$ Once a disaster has occurred, however, FEMA has virtually no options against non-compliant communities and their residents. In particular, FEMA has been barred from recouping its expenditures on insured properties within non-compliant communities. ${ }^{453}$

As a necessary complement to strengthening FEMA's enforcement capabilities, Congress should require FEMA to collect and disseminate accurate, user-friendly information to floodplain communities and residents. Information, education, and outreach are essential to counteract the underlying motivations for individuals to forego insurance. Absent accurate, readily accessible information, people regularly underestimate the likelihood of low-probability but potentially catastrophic events like major floods. ${ }^{454}$ The terminology used by meteorologists, the Corps, and FEMA-relying on 100-year flood predictionsexacerbates the problem. As noted above, the average homeowner perceives a 100-year flood risk as an assurance that once there has been a 100-year flood in the area, she will be safe for the next ninety-nine years-a "gambler's fallacy." 455 Governments and individuals alike are susceptible to these cognitive biases; both "are entirely capable of betting substantial amounts of their welfare (and that of others) on the long-term

448. FEMA is currently engaged in a map modernization project. See Federal Emergency Management Agency, Map Modernization Overview, http://www.fema.gov/plan/prevent/fhm/mm_main.shtm (last visited Sept. 16, 2007).

449. See Flood Insurance Reform and Modernization Act of 2007, supra note 431. At present, non-complying lenders are subject to little more than a slap on the wrist- $\$ 350$ per offense, with penalties capped at \$100,000. See 42 U.S.C.A. $\$ 4012 \mathrm{a}(\mathrm{f})(5)$ (West 2002).

450. McMillan, supra note 166, at 501-02.

451. See supra notes 201-07, 43-31, and accompanying text.

452. 42 U.S.C.A. § 4022(a)(1). See Nat'l Wildlife Fed'n v. FEMA, 345 F. Supp. 2d 1151, 1165 (W.D. Wash. 2004) (holding that FEMA had no discretion under NFIP to deny insurance to persons in eligible communities, and therefore FEMA had no consultation duty under the Endangered Species Act regarding the effects on threatened species of selling insurance).

453. United States v. Parish of St. Bernard, 756 F.2d 1116, 1123 (5th Cir. 1985) (rejecting FEMA's attempt to recover expenditures paid to insureds in communities that failed to enforce their floodplain ordinances on the grounds that neither the NFIP nor common law provided a cause of action).

454. Scales, supra note 3 , at 9 .

455. Id. 
absence of catastrophe."456

A second motivation for foregoing flood insurance probably cannot be countered with information or education, but rather requires regulation and even penalization. At least some occupants abstain from purchasing or maintaining flood insurance because they expect to obtain "free insurance" from the government later in the form of low-interest loans, grants, and other types of post-disaster relief. ${ }^{457}$ This is a form of moral hazard. Moral hazard, a theory employed by economists, posits that rational actors take action to protect themselves only when benefits exceed risks, and that they will take a risk whenever someone else pays for the consequences. ${ }^{458}$ Government programs that protect members of the public from the risks of natural hazards like flooding feed the moral hazard and, consequently, increase improvident construction in the floodplain. ${ }^{459}$ "No private insurer would tolerate the blatant moral hazard at work here, and it is hard to know whether one should be astonished more by the shameless refusal of NFIP participants to rebuild or relocate so as to minimize risk or by the incompetent bureaucracy that continued to tolerate it."460 Legal reforms may not be capable of dictating morality, but legal reforms can and should ensure bureaucratic competency through enhanced regulatory capabilities and continuing congressional and judicial oversight.

The third reform would tackle the so-called repetitive loss problem. This proposal addresses both the "moral hazard" and the obduracy of floodplain developers and occupants by eliminating relief payments for repetitive loss properties. Historically, just one percent of NFIP-insured properties accounts for almost thirty percent of all NFIP losses because of repetitive claims. ${ }^{461}$ Between 1978 and 2004, nearly 113,000 structures experienced either four or more flood losses or at least two losses that equaled or exceeded the structure's value. ${ }^{462}$ This underscores the fact that private actors have the capacity-indeed the incentive-to offload the risk of catastrophic floods onto others rather than to avoid it. ${ }^{463}$ The NFIP plays into this impulse by allowing repairs to repetitive loss homes that suffer severe damage, so long as the damage is less than fifty percent of replacement value. ${ }^{464}$

456. Id. at 12 .

457. Id. at 10. See Drew \& Treaster, supra note 434, at A1 (reporting that nearly half of the victims of Hurricane Katrina did not have flood insurance).

458. Malcolm Gladwell, The Moral-Hazard Myth: The Bad Idea Behind Our Failed Health-Care System, The New Yorker, Aug. 29, 2005, available at http://www.newyorker.com/fact/content/articles/050829fa_fact; Robert E. Schenk, Moral Hazard and Adverse Selection (2006), http://ingrimayne.com/econ/RiskExclusion/Risk.html (last visited Sept. 7, 2007).

459. Hausrath, supra note 178 , at 184 . Welfare and unemployment are cited as examples of programs that encourage moral hazard by persuading some people to work less. Id.

460. Scales, supra note 3 , at 13 .

461. Id. at 13 (citing KING, supra note 173, at CRS-20).

462. National Flood Programs and Policies, supra note 408, at 81.

463. Scales, supra note 3 , at 21 .

464. 42 U.S.C.A. $§ 5154(a)(1)$ (West 2002); McMillan, supra note 166, at 502. 
In addition to rebuilding vulnerable structures, floodplain occupants are allowed to seek emergency services as many times as needed, whether or not they have purchased flood insurance. ${ }^{465}$ Under the NFIP, applicants for federal financial assistance (disaster relief loans or grants) must purchase and maintain flood insurance, but other disaster-related services may be provided regardless of whether the claimant purchased insurance. ${ }^{466}$ It is unrealistic to suggest that governments should deny all disaster relief, including emergency services, to homeowners who refuse to purchase flood insurance. Any reform that compelled the denial of emergency services for uninsured victims would be dead-on-arrival in Congress. Few if any senators or representatives would go on record as voting against emergency services for victims suffering from the likes of Hurricane Katrina. And, as a practical matter, few if any National Guard members would be willing to check insurance coverage before rescuing a desperate resident from a rooftop.

A more viable reform option is to require demolition of repetitive loss structures and also require that any financial relief provided and any insurance proceeds available for those structures be used to relocate affected occupants. Once those occupants are moved out of harm's way, no new construction should be allowed. Although Congress authorized a pilot program in 2004 to reduce expenditures on repetitive loss properties, no long-range institutional changes have been adopted to date. ${ }^{467}$

One final point is worth mentioning. Why not eliminate subsidies altogether? We believe that subsidies should be scaled back, but not completely eradicated. As in the proposed reform bill of $2007,{ }^{468}$ we agree that federal financial largesse should be withdrawn from vacation homes and nonresidential properties. Premiums reflecting market rates are necessary to let consumers know that "lakeshore views are expensive" 469 and to bring home the "[all-too] comfortable paradox" of living in a floodplain. ${ }^{470}$ But location-specific subsidies should continue for existing residences of homeowners who cannot afford market rates for catastrophic flood coverage for several reasons. ${ }^{471}$

465. Davidson, supra note 194 , at 376.

466. 42 U.S.C.A. § 5154(b). This gives applicants "one free bite" of financial aid before they are required to obtain flood insurance. Houck, supra note 149, at 131.

467. McMillan, supra note 166, at 502-03 (citing Hearing on National Flood Insurance Reform Before the S. Comm. on Banking, Housing and Urban Affairs, 109th Cong. (2006) (statement of FEMA Director David Maurstad)). Director Maurstad represented that the Severe Repetitive Loss Pilot Program, applicable to properties with two large claims payments or four smaller claims payments, was in the final stages of development as of August 2006. Id.; see also 42 U.S.C.A. § 4102a(b). Program funds can be used by a state or community to purchase repetitive loss properties outright or to support "mitigation activities that reduce flood damages . . . including elevation, relocation, demolition, and floodproofing of structures, and minor physical localized flood control projects, and the demolition and rebuilding of properties to at least Base Flood Elevation or greater, if required by any local ordinance." 42 U.S.C.A. § $4102 \mathrm{a}(\mathrm{c})$.

468. See Flood Insurance Reform and Modernization Act of 2007, supra note 431.

469. Scales, supra note 3, at 44.

470. Wilkerson, supra note 13 , at 41.

471. Scales, supra note 3 , at 45 . 
First, maintaining these residences in the risk pool may be a necessary evil. Flood insurance represents an "adverse selection problem"-those who are most likely to buy it are those who are the most likely to suffer catastrophic losses. ${ }^{472}$ Private insurers cannot make a profit because the motivated pool of actual purchasers is much riskier than the pool of all potential purchasers. ${ }^{473}$ As a result, insureds that pose reasonable risks, like those living outside of the floodway or the 100-year floodplain, would not participate because their premiums would be grossly inflated to cover the riskiest insureds. ${ }^{474}$

Moreover, past efforts demonstrate that even the withdrawal of federal subsidies is not sufficient to halt unwise construction. The 1982 federal Coastal Barrier Resource Act precluded any new federal financial assistance for the development of certain coastal barriers, barrier islands, adjacent wetlands, and near-shore waters in certain areas along the Atlantic, Gulf, and Great Lakes coasts. ${ }^{475}$ Congress recognized that these areas "serve as natural storm protective buffers and are generally unsuitable for development because they are vulnerable to hurricane and other storm damage," 476 and specifically conceded that, in the past, federal programs had "subsidized and permitted development on coastal barriers and the result has been the loss of barrier resources, threats to human life, health, and property, and the expenditure of millions of tax dollars each year." 477 The Coastal Barrier Resource Act is premised on the belief that, without federal assistance, the risk and potential costs of coastal construction will be prohibitive and developers will stay away. ${ }^{478}$ In some instances, this assumption was correct. ${ }^{479}$ In the most lucrative

472. Id. at 8 .

473. Id.

474. Id. at 8-9 (explaining that, absent some form of subsidy, "such a pool will eventually collapse, as the necessary rise in premiums reshapes the pool into an increasingly narrow band of highly risky consumers who (at some point) can no longer afford the actuarially correct premium").

475. 16 U.S.C.A. $\$ 3504$ (West 2001). See Elise Jones, The Coastal Barrier Resources Act: A Common Cents Approach to Coastal Protection, 21 EnvTl. L. 1015, 1015 (1991) ("By withdrawing federal assistance that encourages building on undeveloped coastal barriers, the Act helps protect valuable natural resources while simultaneously minimizing the wasteful spending of federal tax dollars and the loss of human life and property."). Later, through the Coastal Barrier Improvement Act of 1990, Congress tripled the amount of affected land. Pub. L. No. 101-591, 104 Stat. 2931 (1990) (codified at 16 U.S.C.A. § 3501, $\S 3503)$.

476. 16 U.S.C.A. § 3501(a)(3).

477. 16 U.S.C.A. \$ 3501(a)(4). The system includes 585 units, which total 1.3 million acres of land and associated aquatic habitat. U.S. Fish \& Wildlife Service, John H. Chafee Coastal Barrier Resources System, http://www.fws.gov/habitatconservation/cbra3.htm (last visited Sept. 15, 2007).

478. Jones, supra note 475 , at 1017.

479. Studies that have compared the rate of development of parcels within an affected unit to the development rate of parcels just outside of the unit concluded that, in general, covered units were developing at only half the rate of non-covered units. DAVID SALVESEN \& David R. Godschalk, Development on Coastal Barriers: Does the Coastal Barrier Resources Act Make A Difference? 40-41 (2002); David Salvesen, The Coastal Barrier Resources Act: Has It Discouraged Coastal Development?, 33 CoAstal Mgmt. 181-95 (2005). See also Walter Rosenbaum, The Developmental and Envi- 
markets, however, the legislation appears to have failed. Development continues apace, due to the willingness of state and local governments to provide their own development subsidies and the willingness of developers and purchasers to secure expensive private insurance. ${ }^{480}$ Over two decades of experience with the Act illustrate the need for more stringent controls on floodplain use in tandem with insurance-related reforms. ${ }^{481}$

\section{B. Reforming the Regulatory Takings Doctrine}

In the wake of the Supreme Court's increasing interest in the regulatory takings doctrine-as evidenced by decisions such as First Evangelical Lutheran Church and Lucas ${ }^{482}$ - many floodplain and coastal managers became correspondingly nervous about the constitutionality of land use regulations that limit construction in flood-prone areas. 483 As a result, as one prominent scholar observed, this "regulatory abdication, along with misguided federal subsidies encouraging coastal development, helped produce a building boom that contributed to the tragic losses in [the 2005] hurricanes." ${ }^{844}$ Despite the Supreme Court's perceived hostility to regulation, however, floodplain and coastal ordinances have not triggered a steady stream of judicial opinions imposing liability under the Fifth Amendment. Instead, many lower courts have declined to hold that floodplain regulation constitutes a regulatory taking, either based upon the facts of the individual case or upon the defenses recognized by the Supreme Court.

Three lines of decision in the lower courts are of particular interest. First, increasingly courts have been reluctant to find that flood hazard regulation constitutes a "total taking" under Lucas, instead recognizing significant value remaining in undeveloped lands. Massachusetts has been particularly aggressive in this regard. In Gove v. Zoning Board of

ronmental Impacts of National Flood Insurance: A Review of Literature 6 (2005), available at http://www.fema.gov/library/file?type=publishedFile \&file=nfip_eval_ dei_literature_review.pdf $\&$ fileid $=6855 \mathrm{f} 970-\mathrm{f} 41 \mathrm{f}-11 \mathrm{db}-8 \mathrm{f} 7 \mathrm{c}-000 \mathrm{bdba} 87 \mathrm{~d} 5 \mathrm{~b}$ (concluding that developmental pressures on coastal barrier areas "are sufficiently intense that the absence of NFIP insurance does not inhibit development in some units").

480. SAlveson \& Godschalk, supra note 479, at viii, ix. In addition, some developers and purchasers have been willing to privately finance water mains, treatment plants, and other forms of protective infrastructure. $I d$.

481. See supra Part VI.A.1 (proposing measures for wetlands conservation in the floodplain); infra Part VI (proposing substantive standards and planning requirements for floodplain management).

482. See infra Part V.C.

483. See, e.g., Jon A. Kusler \& Edward A. Thomas, No Adverse Impact: FloodPLAIN MANAGEMENT AND THE COURTS 25 (2005), available at http:/www.floods.org/ NoAdverseImpact/Nai_Legal_Paper_102805.pdf (noting that "governments are often fearful that the [flood hazard] regulations they adopt will be held a 'taking," but concluding that liability under the regulatory takings doctrine is "an overrated economic threat to public coffers"); John D. Echeverria, Time to Overturn “Lucas”, NAT'L L.J., Nov. 14, 2005 (noting that South Carolina withdrew its coastal setback requirement in the aftermath of Lucas and that "[o]ther state and local governments along the U.S. shoreline also responded to the decision by abandoning (or declining to adopt) similar requirements").

484. Echeverria, supra note 483. 
Appeals of Chatham, ${ }^{485}$ for example, the Massachusetts Supreme Court held that a state regulation banning without exception all new residential construction on land within the 100-year coastal floodplain ${ }^{486}$ did not constitute a "total taking" under Lucas. The court was influenced, in part, by alternative uses available to the landowner, including fishing, shellfishing, recreation, utility installation, and agriculture. ${ }^{487}$

Second, lower courts have begun to recognize floodplain/coastal construction as a nuisance (or nuisance-like) activity that qualifies for the Lucas "background principles" defense to categorical liability. The courts of Rhode Island have been perhaps most aggressive in this regard. In Palazzolo v. Rhode Island, the United States Supreme Court heard a takings challenge to the denial of a permit to fill and develop approximately eighteen acres of coastal salt marsh. ${ }^{488}$ Finding the claim to be ripe, the Supreme Court remanded the case for a resolution of the takings claim. 489 On remand, the Rhode Island court found that the proposed wetland development would constitute a public nuisance. ${ }^{490}$ Without more, the court held that nuisance would serve as a "preclusive defense" to the regulatory takings challenge. 491

Similarly, the Fifth Circuit issued a sweeping endorsement of the NFIP and corresponding land-use regulations. ${ }^{492}$ In dismissing a facial chal-

485. Gove v. Zoning Bd. of Appeals, 831 N.E.2d 865 (Mass. 2005).

486. The subject property lay entirely within "Zone A," an area designated by the Federal Emergency Management Agency as vulnerable to "[s]ignificant flooding" during "hundred year storms." Id. at 868 .

487. Id. at 869 n.7. The court also held that the challenged regulations did not constitute a regulatory taking under the traditional multi-factor test applicable in situations where regulations fail to deprive land of all economically beneficial use. Id. at 873-75. See also State Dep't of Envtl. Prot. v. Burgess, 772 So.2d 540, 543 (Fla. Dist. Ct. App. 2000) (rejecting regulatory taking challenge to denial of dredge-and-fill permit for construction of dock, boardwalk, and camping shelter on undeveloped 160-acre wetland, and concluding that the landowner "utterly failed to demonstrate that the permit denial deprived him of all reasonable economic use of his land").

488. Palazzolo v. Rhode Island, 533 U.S. 606, 632 (2001) (finding 1986 denial of application for dredge-and-fill permits for beach facility ripe for review).

489. Id. at 632 .

490. Palazzolo v. Rhode Island, No. WM 88-0297, 2005 WL 1645974, at *5 (R.I. Super. July 5, 2005).

491. Id. See also R\&Y, Inc. v. Municipality of Anchorage, 34 P.3d 289, 300-01 (Alaska 2001) (rejecting regulatory taking challenge to municipal regulation prohibiting development within 100 feet of particular wetland, noting the ecosystem services provided by functioning wetlands). See generally Klein, supra note 357.

Although the Lucas Court recognized the nuisance/background principles analysis as a defense to total takings claims, other courts have applied the defense to obviate the need to consider the Penn Central factors. See Michael C. Blumm \& Lucus Ritchie, Lucas's Unlikely Legacy: The Rise of Background Principles as Categorical Takings Defenses, 29 Harv. Envtl. L. Rev. 321, 322 (2005) (observing that "rather than heralding in a new area of landowner compensation or government deregulation, Lucas instead spawned a surprising rise of categorical defenses to takings claims in which governments can defeat compensation suits without case-specific inquiries into the economic effects and public purposes of regulations").

492. See Adolph v. Fed. Emergency Mgmt. Agency, 854 F.2d 732, 734-35 (5th Cir. 1988). Ironically, Adolph represented a challenge to land use/flood hazard restrictions adopted by Plaquemines Parish, an area that was later devastated in 2005 by Hurricane Katrina. See supra note 261 and accompanying text. See also Deltona Corp. v. United 
lenge to the NFIP, the court held that as a matter of law, the NFIP - as well as local land-use regulations tracking its criteria-do not constitute regulatory takings. ${ }^{493}$ Interestingly, the court cited to the dissenting opinion of First English Evangelican Lutheran Church of Glendale v. County of Los Angeles 494 for the proposition that, as a matter of law, the "regulatory program at issue ... cannot constitute a taking." 495 Although the Fifth Circuit left open the possibility that the application of the statute to a particular parcel of land might require compensation, ${ }^{496}$ it indicated this to be unlikely, even where flood control measures effectively eliminate all commercial value of the property. ${ }^{497}$ In particular, the court was influenced by the nature of flood management, which prevents some landowners from imposing nuisance-like danger upon others. ${ }^{498}$ Other courts have gone even farther than the Fifth Circuit, rejecting takings challenges to local ordinances that are significantly more restrictive than that re-

States, 657 F.2d 1184, 1193-94 (Ct. Cl. 1981) (rejecting as a matter of law takings challenge to flood management ordinance).

493. Adolph, 854 F.2d at 735, 740. See also Wild Rice River Estates, Inc. v. City of Fargo, 705 N.W.2d 850, 853 (N.D. 2005) (rejecting temporary regulatory taking challenge to twenty-one month moratorium on the issuance of floodway building permits pending enactment of floodplain ordinance consistent with FEMA floodplain map, and noting that the subject property had been submerged by 1997 flood and that the Wild Rice River had "a long and significant history of flooding"); Grenier v. Zoning Bd. of Appeals of Chatham, 814 N.E.2d 1154, 1161-62 (Mass. App. Ct. 2004) (holding that zoning ordinance prohibiting residential construction within 100-year floodplain was not a regulatory taking).

494. 482 U.S. 304, 322 (1997) (Stevens, J., dissenting); see supra notes 373-78 and accompanying text.

495. Adolph, 854 F.2d at 736 .

496. Id. at 740 .

497. Id. at 735 .

498. Id. at 739 n.10 (observing that "[f]lood-hazard zoning and other regulations serve a vital purpose in protecting the people who occupy the regulated land and in protecting neighboring landowners from increased flood damage and in protecting the general public" and noting that flood regulations involve "the safety of lives and property, not merely environmental or aesthetic considerations"). See also Wyer v. Bd. of Envtl. Prot., 747 A.2d 192, 193-94 (Me. 2000) (upholding denial of variance for construction in sand dune); Andrews v. Town of Amherst, 862 N.E.2d 65, 71 (Mass. App. Ct. 2007) (outside context of regulatory takings, upholding validity of zoning amendment in area that had previously been subject to flooding in the wake of Hurricane Floyd); Poster v. Strough, 299 A.D.2d 127, 143 (N.Y. App. Div. 2002) (affirming lower court's finding that town's policy against revetments and other "hard stabilization" structures to stabilize shoreline was not arbitrary and capricious, and questioning whether hard structures may do more harm than good).

Prior to Lucas, a number of courts supported floodplain regulations against takings challenges. See Turner v. County of Del Norte, 24 Cal. App. 3d 311 (Cal. Ct. App. 1972) (upholding county ordinance limiting floodplain uses to parks, recreation, and agriculture); Sarasota County v. Purser, 476 So. 2d 1359, 1363 (Fla. Dist. Ct. App. 1985) (upholding denial of special exception for mobile home park in floodplain); Turnpike Realty Co. v. Town of Dedham, 284 N.E.2d 891, 901 (Mass. 1972); Falcone v. Zoning Bd. of Appeals, 389 N.E.2d 1032, 1034 (Mass. App. Ct. 1979) (upholding denial of subdivision application in floodplain); New City Office Park v. Planning Bd., 144 A.D.2d 348, 350 (N.Y. App. Div. 1988) (upholding denial of site plan approval within floodplain); Responsible Citizens of Brockton in Opposition to the Flood Plain Ordinance v. City of Asheville, 302 S.E.2d 204, 214 (N.C. 1983); Kraiser v. Zoning Hearing Bd., 406 A.2d 577, 578 (Pa. Commw. Ct. 1979) (upholding denial of variance for duplex in 100-year floodplain conservation zone); Maple Leaf Investors, Inc. v. State Dep't of Ecology, 565 P.2d 1162, 1165-66 (Wash. 1977) (en banc) (upholding ordinance prohibiting all residential development in floodway). 
quired to qualify for the NFIP. ${ }^{499}$

As a third sign of reform, many courts have declined to find that ordinances limiting floodplain/coastal construction "go too far." For purposes of the three-factor Penn Central analysis, courts make "essentially ad hoc, factual inquiries,"500 including consideration of: (1) the "economic impact of the regulation," (2) the extent to which the regulation interferes with a landowner's "distinct investment-backed expectations," and (3) the "character of the governmental action."501 With respect to the first factor, courts have countenanced rather severe diminutions in value, dismissing them as within "the range of normal fluctuation in the value of coastal property." 502

Likewise-under the second factor-courts have become less willing to accept as "reasonable" expectations for the development of sensitive floodplain and coastal properties. ${ }^{503}$ The highest court in Massachusetts, for example, has found unreasonable the expectation to build residential structures on property within the 100-year flood plain, an area where land is "highly marginal ... , exposed to the ravages of nature, [and] that for good reason remained undeveloped for several decades even as more habitable properties in the vicinity were put to various productive uses." 504

Finally, under the "character of the governmental action" factor, lower courts have become increasingly willing to look favorably upon land use regulation restricting development in flood hazard areas. As the highest

499. See, e.g., Turner, 24 Cal. App. 3d at 311 (rejecting takings challenge as a matter of law to county ordinance limiting floodplain uses to parks, recreation, and agriculture); Brecciaroli v. Conn. Comm'r of Envtl. Prot., 362 A.2d 948, 953 (Conn. 1975) (affirming trial court's rejection as a matter of law, without evidentiary hearing, of takings challenge to denial of wetland filling permit); Pope v. City of Atlanta, 249 S.E.2d 16, 21 (Ga. 1978) (rejecting takings challenge to city plan prohibiting construction of impervious structures in flood plains); Hansel v. City of Keene, 634 A.2d 1351, 1354 (N.H. 1993) (upholding floodplain regulations stricter than NFIP minimum standards); Am. Cyanamid Co. v. Dep't of Envtl. Prot., 555 A.2d 684, 695 (N.J. Super. Ct. App. Div. 1989) (upholding land use regulation affecting 500-year floodplain); Cappture Realty Corp. v. Bd. of Adjustment, 336 A.2d 30, 35 (N.J. Super. Ct. App. Div. 1975) (rejecting takings challenge as a matter of law); Dur-Bar Realty Co. v. City of Utica, 394 N.Y.S.2d 913, 918 (N.Y. App. Div. 1977) (rejecting takings challenge as a matter of law); Responsible Citizens in Opposition to Flood Plain Ordinance, 302 S.E.2d at 212-13; Maple Leaf Investors, Inc., 565 P.2d at 1166 (upholding ordinance prohibiting all residential development within specified flood area, regardless of potential to increase flood levels). See also Andrews, 862 N.E.2d at 71 (in non-regulatory taking case, upholding validity of zoning amendment, and observing, "where a large portion of the locus had been flooded [by Hurricane Floyd], it was not irrational to include more of the locus as a flood prone area than the minimum specified in the by-law for land traversed by a watercourse").

500. Penn Cent. Transp. Co. v. City of New York, 438 U.S. 104, 124 (1978).

501. Id. at 124 .

502. Gove v. Zoning Bd. of Appeals, 831 N.E.2d 865, 872-74 (Mass. 2005) (declining to find that a ninety-three percent diminution in value-from an estimated $\$ 346,000$ to $\$ 23,000$ - runs afoul of the economic impact analysis).

503. Id. at 875 .

504. Id. at 874. See also Forest Props., Inc. v. United States, 177 F.3d 1360, 1366-67 (Fed. Cir. 1999) (rejecting takings challenge to denial of section 404 permit to convert lakebottom property into residential development). 
court of Massachusetts has observed, the construction of homes on land within the 100-year floodplain has the potential to adversely affect neighboring areas, and "[r]easonable government action mitigating such harm . . . typically does not require compensation [under Penn Central]." 505 The court was influenced, in part, by the surrounding area's historical vulnerability to hurricanes, flooding, storm surges, and coastal erosion. ${ }^{506}$

In sum, a growing assemblage, including Congress, the states, the courts, local communities, floodplain experts, and ordinary citizens, has begun to explore alternatives to settlement in disaster-prone areas. Rejecting the unending call for tax dollars to subsidize risk-prone development, they have begun to realize that it makes little sense-from an economic, scientific, or even constitutional perspective-to tolerate building and rebuilding in vulnerable areas.

\section{EPILOGUE: CREATING A MANDATE FOR FEDERAL LEADERSHIP}

The river is within us, the sea is all about us; . .

It tosses up our losses, the torn seine,

The shattered lobsterpot, the broken oar

And the gear of foreign dead men. The sea has many voices,

Many gods and many voices.

-T.S Eliot 507

The Mississippi River has taught many important lessons over the course of the past century. We have attempted to give voice to these lessons through the stories of three events that-extraordinary as they were-are highly likely to be repeated unless bold steps are taken. The federal government, through its floodplain management policies and its flood insurance program, must take the lead, guiding an effort by all levels of government.

Although often overlooked, a federal mandate already exists, including congressional recognition of a strong federal role in land-use planning for

505. Gove, 831 N.E.2d at 875 .

506. Id. at 875 (describing denial of permit to build single-family house on undeveloped land within coastal conservancy district as "[r]easonable government action mitigating . . . harm ... [which] typically does not require compensation"); see also Brace v. United States, 48 Fed. Cl. 272, 278-79 (2000) (remanding for factual development of record in takings challenge to administrative order prohibiting drainage of wetlands, and approving character of the government action implementing its "legitimate public welfare obligation to preserve our nation's wetlands"); Commonwealth v. Blair, No. Civ. A 98-2758-G, 2000 WL 875903, at *7 (Mass. Super. June 6, 2000) (rejecting takings challenge to state statute prohibiting the alteration of land within 200 feet of surface waters within protected watersheds supplying public drinking water and observing, "[t]he character of the government action here, therefore, is much akin to prohibiting acts which may have been prohibited, at least in part, at common law prior to the enactment of the [challenged statute]"). But see Mansoldo v. State, 898 A.2d 1018, 1020-24 (N.J. 2006) (requiring compensation to landowner precluded from constructing homes in floodway, despite "the laudatory goal of limiting flood damage and loss of life along the river").

507. Eliot, The Dry Salvages, supra note 9. 
floodplain and coastal areas. In particular, the Flood Disaster Protection Act of 1973 requires communities seeking eligibility for federal assistance "to adopt adequate flood plain ordinances with effective enforcement provisions consistent with Federal standards to reduce or avoid future flood losses." 508 The federal government is therefore charged with establishing effective standards, reviewing the adequacy of the local ordinances to ensure that they meet the federal standards, and, finally, disqualifying communities that fail to meet the standards. ${ }^{509}$ These federal functions cannot be delegated away. ${ }^{510}$ Indeed, they must be strengthened through both federal financial policies and complementary floodplain management measures.

To ensure the responsible exercise of federal leadership over flood hazard management-traditionally delegated to the Army Corps of Engineers-the hodgepodge of highly discretionary Flood Control Acts, coupled with piecemeal funding of pet projects through Water Resources Development Acts and other earmarks, must be replaced. Instead, Congress should enact a programmatic organic act ${ }^{511}$ for the Mississippi River basin-an Interior Rivers Ecosystem Act. ${ }^{512}$ This statute would serve as a charter for the Corps and the lands and resources it administers by providing an overarching mission statement, supported by clearly delineated designated uses and substantive management criteria, along with comprehensive planning requirements. ${ }^{513}$ Substantive requirements for watershed planning and management would effectuate the Progressive Era objective underlying the original Flood Control Act of 1928: treating the river and its floodplain as an integrated unit from source to mouth, "systematically and consistently," with coordination of navigation, flood control, irrigation, hydropower, and ecosystem services. ${ }^{514}$ To accomplish

508. 42 U.S.C.A. $\$ 4002(b)(3)$ (West 2002) (emphasis added). See supra notes 174-75 and accompanying text (describing the Flood Disaster Protection Act of 1973 and related provisions).

509. 44 C.F.R. $\$ \$ 60.1, .3$ (2007).

510. Platt, supra note 6 , at 27.

511. Programmatic enactments that create or empower administrative agencies and specify their overarching mission are generally known as organic acts. RICHARD J. PIERCE, Jr. et Al., Administrative Law And Process 35, 220 (4th ed. 2004); Robert L. Fischman, The National Wildlife Refuge System and the Hallmarks of Modern Organic Legislation, 29 EcOlOGy L.Q. 457, 502-513 (2002).

512. This recommendation builds on previous reform proposals made in Sandra Zellmer, A Tale of Two Imperiled Rivers: Reflections from a Post-Katrina World, 59 FLA. L. Rev. 599, 628-630 (2007); and Zellmer, A New Corps of Discovery, supra note 121, at 346-57.

513. Zellmer, A Tale of Two Imperiled Rivers, supra note 512, at 627-28.

514. See supra note 106-09 and accompanying text. Senator Russ Feingold has offered several Water Resources Development Act amendments aimed at prioritizing Corps' projects. His latest proposal would require an independent oversight panel and a one-time non-binding report prioritizing projects and recommending future prioritization criteria. See Darren Goode, Managers' Amendment Trims WRDA Reauthorization Bill, Cong. DAILy, May 10, 2007, at 10. According to a press release from Feingold's office, "Th[e] status quo has failed America. The current lack of clear water resource priorities is damaging the nation's economic development, transportation systems, and ability to protect citizens and property from natural disasters." Press Release, Senator Russ Feingold, Sens. 
this objective, the proposed organic act must embrace five basic principles:

(1) Adopt sustainable, ecologically resilient standards and objectives;

(2) Employ comprehensive environmental analysis of individual and cumulative effects of floodplain construction (including wetlands fill); $; 15$

(3) Enhance federal leadership and competency by providing the Corps with primary responsibility for flood control measures, cabined by clear standards, continuing monitoring responsibilities, and oversight through probing judicial review, and supported by a secure, nonpartisan funding source;

(4) Stop wetlands losses and restore damaged floodplains by re-establishing natural areas that are essential for floodwater retention; and

(5) Recognize that land and water policies are inextricably linked and plan for both open space and appropriate land use in the floodplain. ${ }^{516}$

In addition, to ensure accountability, Congress should enact a waiver of sovereign immunity for liability for negligently engineered or maintained flood control devices. At present, the federal government is excused from liability "of any kind ... for any damage from or by floods or flood waters at any place." 517 Thus, the Corps has little incentive to take even the most basic precautions required by the engineering profession. It is shielded from liability for its negligence, despite the fact that, just one year after Hurricane Katrina struck, the Corps admitted culpability for the design and construction flaws that led to the devastation of New Orleans. ${ }^{518}$ A waiver of immunity would motivate the Corps to step up its efforts and engage in, at minimum, due diligence in designing, constructing, and maintaining its flood control devices. ${ }^{519}$ Perhaps it would also take its responsibility to warn the public about the true dangers of occupying the floodplain, levees notwithstanding, more seriously.

No doubt about it, these reforms would result in a stronger federal role in land-use planning. Controversial as this may be, leaving floodplain

Feingold, McCain, Coburn Work to Reform Army Corps of Engineers (May 14, 2007), http://feingold.senate.gov/ feingold/releases/07/05/20070514.html.

515. The National Environmental Policy Act ("NEPA"), 42 U.S.C.A. § 4332(C) (West 2002), requires an analysis of impacts and alternatives of all major federal actions, but levee construction and wetlands fills typically proceed on an individual basis, with little or no analysis of the cumulative effects of multiple projects. Pinter, supra note 205, at 208. See 33 C.F.R. § 320.4 (2007) (recognizing that the cumulative impacts of various individual floodplain alterations "may result in a significant degradation of floodplain values and functions and in increased potential for harm").

516. Bruce Babbitt, Cities in the Wilderness: A New Vision of Land Use in America 115, 130-31 (2005); Oliver Houck, Can We Save New Orleans?, 19 Tul. EnvTl. L.J. 1, 54, 67 (2006).

517. 33 U.S.C.A. § 702(c). See supra note 101 and accompanying text.

518. See supra notes 326-29 and accompanying text.

519. A general waiver of immunity for tort claims is provided in the Federal Tort Claims Act, 28 U.S.C.A. § 2674. See Berkovitz v. United States, 486 U.S. 531, 547-48 (1988) (allowing a tort suit against the United States when the plaintiff contracted polio after taking a vaccine which had been approved for production and distribution by the U.S.). 
management to local governments has led to, at best, fragmentation and, at worst, outright irrational behavior. ${ }^{520}$ If the Mississippi River has taught us nothing else, it provides a constant reminder that rivers have an utter lack of respect for political boundaries. The federal government has long been involved in land-use development through the Corps' engineering and construction activities, the extensive interstate highway program, the construction of reclamation dams throughout the West, and many other federally conducted or federally funded initiatives. It is time for the federal government to take a leadership role in land-use planning in the nation's floodplains as well. By requiring strong federal leadership, the proposed reforms would in turn stimulate more comprehensive planning and coordination by and with local governments-a type of cooperative federalism well-known in environmental law. ${ }^{521}$

The nation's experience with floods and hurricanes during the past century has repeatedly suggested an important lesson: although federal leadership is critically necessary, it must be the right kind of politically and ecologically sound leadership. The proposed organic act would go a long way toward implementing that lesson. Coupled with parallel judicial reform of the regulatory takings doctrine-recognizing that floodplain and coastal regulation does not "take" anything from landowners but the potential to shift risk onto others - the enhanced federal leadership could limit the unnecessary transformation of natural disasters into human disasters.

520. See 1 Arden H. Rathkopf \& Daren A. Rathkopf, Rathkopf's: The Law of Zoning AND Planning $§ 7.16$ (4th ed. 2007) (describing fragmentation as the "most serious problem" with federal floodplain programs); see also BABBITT, supra note 516, at 5 (concluding that "a considerable body of law . . . can and, in my view, should be used toward enhanced federal leadership in land use planning and preservation"); BABBITT, supra note 516, at 61 ("Land use planning has . . . been a federal function since the nation's founding.").

521. See Robert V. Percival, Environmental Federalism: Historical Roots and Contemporary Models, 54 MD. L. REV. 1141, 1173-74 (1995) (describing cooperative federalism as the dominant model of modern environmental law). 
